\title{
An integrated social and ecological modeling framework-impacts of agricultural conservation practices on water quality
}

\author{
$\underline{\text { Irem Daloğlu }}{ }^{1}, \underline{\text { Joan Iverson Nassauer }}^{1}$, Rick Riolo $^{2}$ and Donald Scavia $^{1,3}$
}

\begin{abstract}
We present a modeling framework that synthesizes social, economic, and ecological aspects of landscape change to evaluate how different agricultural policy and land tenure scenarios and land management preferences affect landscape pattern and downstream water quality. We linked a stylized agent-based model (ABM) of farmers' conservation practice adoption decisions with a water quality model, the Soil and Water Assessment Tool (SWAT), to simulate the water quality effects of changing land tenure dynamics and different policies for crop revenue insurance in lieu of commodity payments over 41 years (1970-2010) for a predominantly agricultural watershed of Lake Erie. Results show that non-operator owner involvement in land management decisions yields the highest reduction in sediment and nutrient loads, and crop revenue insurance leads to more homogeneous farmer decisions and a slight increase in sediment and nutrient loads unless cross compliance with expanded conservation requirements is implemented.
\end{abstract}

Key Words: ABM; agricultural policy; agriculture; conservation practice; integrated modeling; SWAT; water quality

\section{INTRODUCTION}

Agricultural policy in the USA strongly impacts the land use and land management decisions of farmers and indirectly, but profoundly, impacts water quality (Broussard et al. 2012). An overall goal of conservation policies with regard to water quality is to reduce sediment and nutrient load from agricultural landscapes by promoting nutrient efficiency and managing nutrient and sediment runoff through conservation best management practices (Sharpley et al. 1994). Thus, detailed studies of the connections between agricultural policies and water quality can help identify more effective strategies to reduce agricultural pollution.

High surface water concentrations of nitrogen and phosphorus are correlated with inputs from fertilizers used for crops (Ribaudo and Smith 2000, Boyer et al. 2002, Galloway et al. 2004). For example, the current resurgence of eutrophication symptoms in the Great Lakes is attributed to the intensification in agricultural production and concomitant soil erosion and nutrient runoff from nonpoint sources (Dolan and Chapra 2012). To address these issues, conservation practices, such as conservation tillage, filter strips, land retirement, and nutrient management - the focus of this research-are employed to mitigate sediment and nonpoint source nutrient delivery, enhance water quality, and improve sustainability in agricultural production by increasing resilience (National Research Council 2010).

The focus of this study is the impact of plausible future policy and land tenure scenarios on the delivery of bioavailable dissolved reactive phosphorus (DRP) and total phosphorus (TP) to Lake Erie by exploring links between human and environmental systems. We describe a social-ecological system (SES) that links farmer decisions and actions to ecological responses in reciprocal feedbacks. Social-ecological systems are affected by complex relationships arising from the biophysical, institutional, infrastructural, demographic, economic, and sociopolitical contexts. Hence, SESs exhibit emergent properties-unique properties not belonging to human or natural systems separately but emerging from their interactions (Janssen 1998, Monticino et al. 2007, Rammel et al. 2007, Levin et al. 2012). Understanding the complexities of SESs may affect the success or failure of their management (Liu et al. 2007). Unforeseen and undesirable consequences can result if biophysical and human systems are not examined together (Veldkamp and Verburg 2004, Levin et al. 2012).

We describe an SES model to investigate the impact of different plausible future policy and land tenure scenarios on farmer adoption of conservation practices intended to enhance water quality. We link a social agent-based model (ABM) of farmer adoption of conservation practices with a biophysical water quality model, the Soil and Water Assessment Tool (SWAT), which integrates land management decisions with soil properties, climate information, and land topography to estimate water quality metrics (Arnold et al. 1998). We define farmers as owners or renters of land on which cash crops are grown, who make decisions about land management based on policy scenarios involving economic, institutional, and environmental information. This ABM incorporates the heterogeneity and complexity of Corn Belt farmers through a typology (Daloğlu et al. in review) that simulates farmer decisions in terms of their tendency toward adoption of conservation practices.

\section{THE MODELING FRAMEWORK}

The study area is the Sandusky watershed of Lake Erie, which represents a typical watershed of the Corn Belt region (Fig. 1). Lake Erie has experienced significant eutrophication because of excessive phosphorus loading, primarily from agricultural runoff and point-source discharges (Dolan and Chapra 2012); however, non-point sources, particularly from agriculture, are currently the major causes of nutrient pollution (Forster 2000). Agricultural runoff has resulted in algal blooms (Michalak et al. 2013), poor water clarity, and summer hypoxia (low oxygen) (Hawley et al. 2006, Zhou et al. 2013, Scavia et al. 2014) that impact fisheries,

${ }^{1}$ School of Natural Resources and Environment, University of Michigan, ${ }^{2}$ Center for the Studies of Complex Systems, University of Michigan,

${ }^{3}$ Graham Environmental Sustainability Institute, University of Michigan 
recreation, and drinking water throughout many aquatic and coastal systems (Carpenter 2008). To address these issues, effective adoption of conservation practices is essential.

Fig. 1. Locator map for the Sandusky Watershed, Ohio. The study watershed is representative of Corn Belt watersheds (striped region).
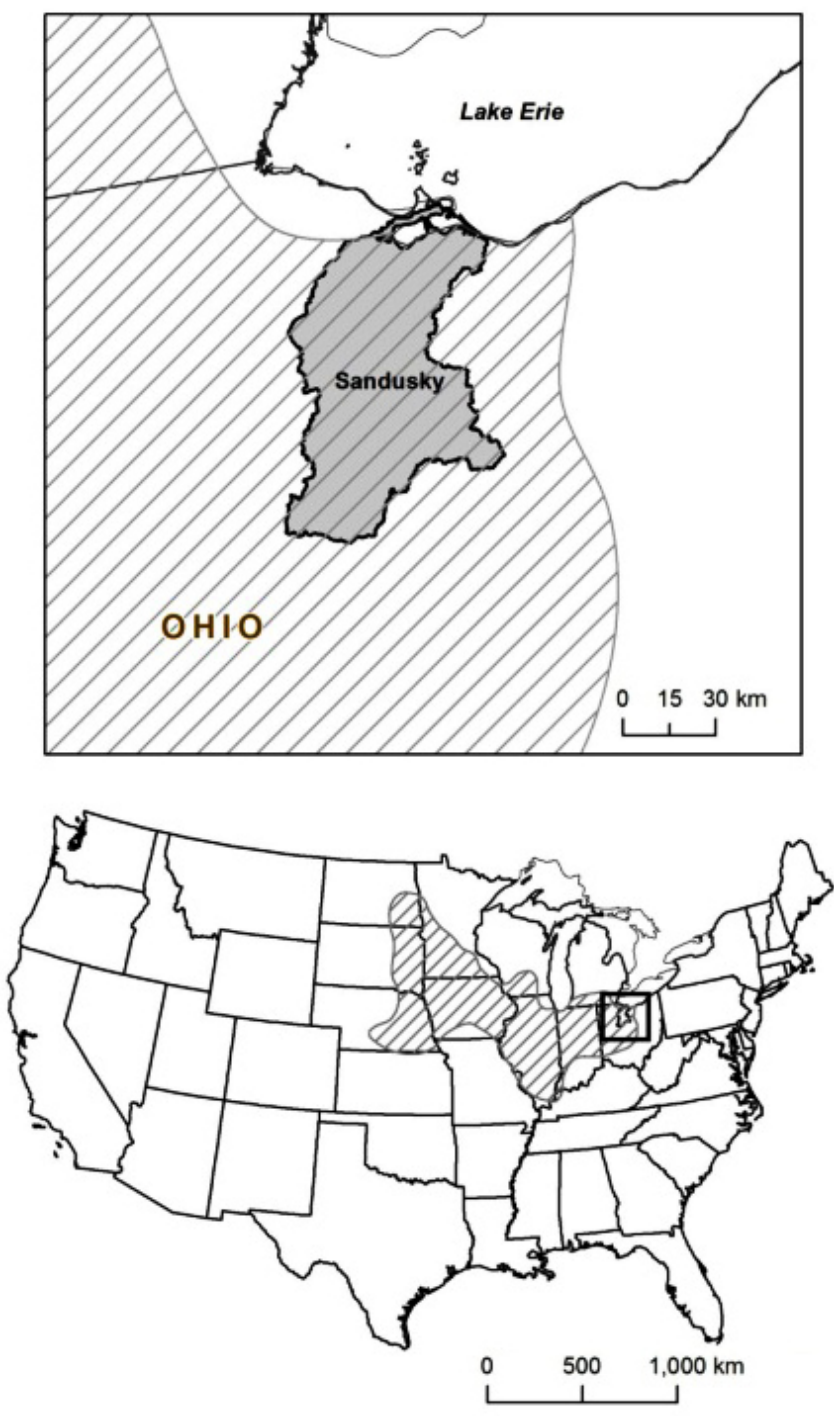

With our linked ABM-SWAT framework, we investigate how policy and farmer characteristics influence conservation practice selection and, in turn, their effects on water quality. The framework - the ABM is implemented in Java using Repast $\mathbf{J}$ agent-based libraries within the Eclipse integrated environment and linked to SWAT using MatLab - includes the landscape, agents (farmers, in a typology that represents their heterogeneity), conservation practice adoption, and ecosystem responses (sediment, DRP, and TP loading) to changes in land management (Fig. 2). The farmer typology (Daloğlu et al. 2014) represents the heterogeneity among Corn Belt farmers and provides the necessary pillar for the ABM. An existing fully calibrated and verified SWAT model of the Sandusky watershed (Daloğlu et al. 2012) is used to simulate nutrient load responses.
Fig. 2. The coupled human and natural system of an agricultural landscape in the Corn Belt.
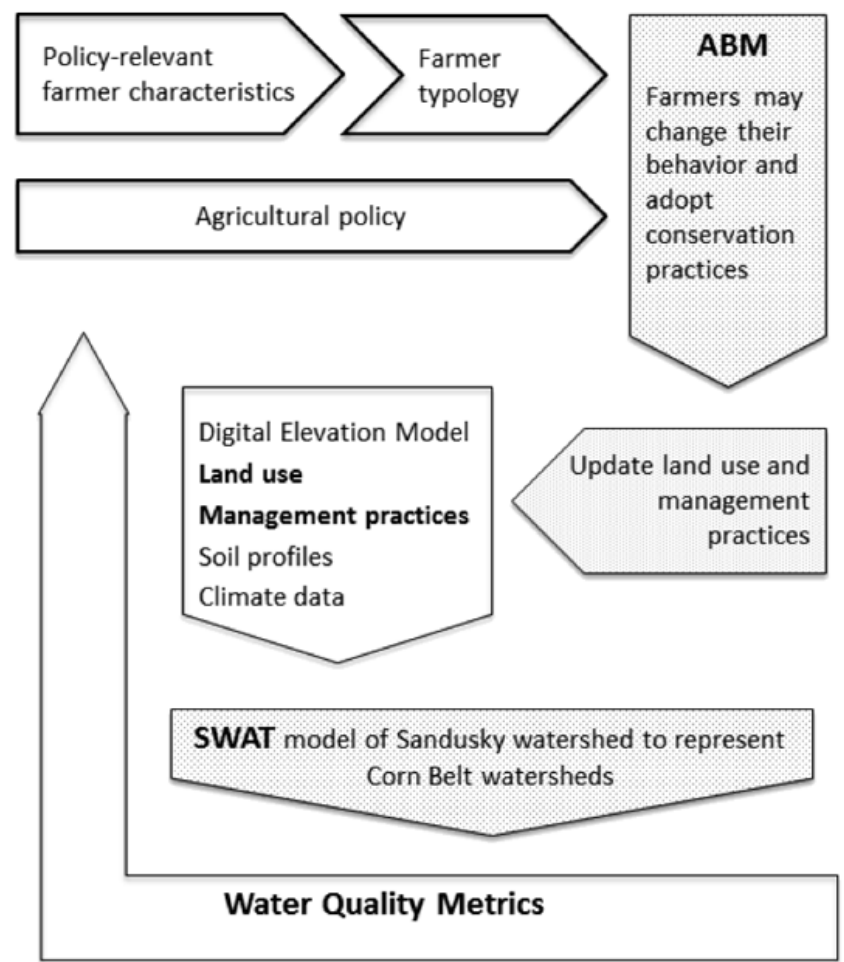

Water Quality Metrics

The ABM is constructed at the individual decision-making level, and so we use our farmer typology to represent farmer behavior and decisions. In the model, farmer agents of different types make adoption decisions every year based on decision algorithms. If farmer decisions include the adoption of conservation practices, the landscape is altered, which eventually changes the land management strategy. Through this model, we explore possible changes in the structure of U.S. agriculture through land tenure dynamics and the influence of crop revenue insurance on farmers' conservation practice adoption decisions.

The output from the ABM, in the form of updated land management maps (Fig. 2), is used to examine the impacts of these changes as presented in plausible future scenarios. To understand the impacts of these scenarios, SWAT is used to simulate sediment and phosphorus loss from the landscape over a 41-year period (1970-2010).

\section{The Model Landscape}

The model landscape consists of a two-dimensional grid, built within the ABM, abstractly representing the agricultural landscape of the Sandusky watershed. Because the ABM is linked with the SWAT, the specifics of the water quality model are taken into consideration during ABM setup. The SWAT uses hydrologic response units (HRU) as its fundamental computational unit. Runoff flow, sediment, and nutrient loads are calculated separately for each HRU and then summed to determine the total load contribution from each subwatershed (Neitsch et al. 2011). Land management decisions are represented at the HRU scale; 
Table 1. Farmer typology (from Daloğlu et al., unpublished manuscript)

\begin{tabular}{|c|c|c|}
\hline Farmer Type & Land tenure, income and information network properties & Land Management Preferences \\
\hline Traditional & $\begin{array}{l}\text { Full-owner, small operations, dependent on on-farm income, } \\
\text { moderately connected to information networks }\end{array}$ & $\begin{array}{l}\text { - favor nonstructural practices because of potential reduction } \\
\text { in labor requirements } \\
\text { - financial investment requirement leads to lower adoption } \\
\text { rates for structural practices } \\
\text { - secure income provided by land retirement programs is } \\
\text { appealing }\end{array}$ \\
\hline Supplementary & $\begin{array}{l}\text { Full/Part-owner, small operations, has off-farm income, } \\
\text { moderately connected to information networks }\end{array}$ & $\begin{array}{l}\text { - favor nonstructural practices because of potential reduction } \\
\text { in labor requirements } \\
\text { - substantial off-farm income leads to higher adoption rates } \\
\text { for structural practices. } \\
\text { - secure income provided by land retirement programs is } \\
\text { appealing }\end{array}$ \\
\hline Business-oriented & $\begin{array}{l}\text { Part-owner, medium to large operations, dependent on on- } \\
\text { farm income, highly connected to information networks }\end{array}$ & $\begin{array}{l}\text { - favor nonstructural practices because of potential reduction } \\
\text { in labor requirements } \\
\text { - long-term plans and dependence on soil quality leads to } \\
\text { higher structural practice adoption } \\
\text { - focused on profitability, leading to low enrollment rates in } \\
\text { land retirement programs }\end{array}$ \\
\hline Nonoperator owner & $\begin{array}{l}\text { Nonoperator owner, medium to large operations, has off- } \\
\text { farm income, least connected to information networks }\end{array}$ & $\begin{array}{l}\text { - have less control on land management strategies but positive } \\
\text { attitudes toward conservation practices }\end{array}$ \\
\hline
\end{tabular}

we used an HRU size corresponding to the average farm size in the Sandusky basin (258 acres; United States Department of Agriculture (USDA) 2009, Daloğlu et al. 2012). This strategy resulted in 147 subbasins and 351 agricultural HRUs. Therefore, 351 farmers are represented as agents in the ABM.

\section{Agents as Farmers}

Farmers are exceptionally diverse, particularly with regard to farm size, land tenure, education, age, sources of income, and socioeconomic attributes. To represent this heterogeneity in the ABM, we used a typology (Table 1; Daloğlu et al. 2014) derived from an extensive literature review and previous surveys conducted in the Corn Belt region. Because ABMs require simplicity (Axelrod 1997), like others (Valbuena et al. 2008, Robinson et al. 2012), our typology represents diversity and heterogeneity in simple terms based on four farmer types: traditional, supplementary, business-oriented, and nonoperator owners (Table 1) (Daloğlu et al. 2014).

Because of limited data, it is not possible to identify exact locations of farms and management decisions. Therefore, we chose to represent the study area in a more stylized model, as described in Appendix 1, using the "overview, design concepts, and details” (ODD) protocol (Grimm et al. 2010).

\section{Conservation Practices}

We define land management as driven by four conservation practices and government programs that are widely used and could be represented in SWAT (Table 2). In the model, farmers can adopt combinations of conservation practices to control pollution sources (nutrient management), trap soil and nutrients before they reach water bodies (structural practices, i.e., filter strips), promote long-term conservation covers (land retirement, i.e., Conservation Reserve Program (CRP)), and reduce soil disturbance (nonstructural practices, i.e., conservation tillage and no-till). Farmers' annual adoption decisions are then explored under the influence of different future scenarios.
Table 2. Conservation practice categories applicable in SWAT models (modified and adapted from Daloğlu et al., unpublished manuscript).

\begin{tabular}{|c|c|c|}
\hline $\begin{array}{l}\text { Conservation } \\
\text { Practice Categories }\end{array}$ & $\begin{array}{l}\text { Conservation } \\
\text { Practices }\end{array}$ & $\begin{array}{l}\text { Economic and Environmental } \\
\text { Benefits }\end{array}$ \\
\hline Nonstructural & $\begin{array}{l}\text { Conservation } \\
\text { tillage, no-till }\end{array}$ & $\begin{array}{l}\text { Reduces soil erosion from both } \\
\text { water and wind, increases organic } \\
\text { matter, and enhances water } \\
\text { quality. Reduces labor, saves time } \\
\text { and fuel, reduces machine wear }\end{array}$ \\
\hline Structural & $\begin{array}{l}\text { Filter strips, } \\
\text { grassed } \\
\text { waterways }\end{array}$ & $\begin{array}{l}\text { Enhances water quality by } \\
\text { trapping soil particles, nutrients, } \\
\text { and pesticides; improves water } \\
\text { infiltration; enhances wildlife } \\
\text { habitat. Eligible for cost-share } \\
\text { programs }\end{array}$ \\
\hline Land retirement & $\begin{array}{l}\text { Conservation } \\
\text { Reserve } \\
\text { Program } \\
\text { (CRP) }\end{array}$ & $\begin{array}{l}\text { Plants long-term, resource } \\
\text { conserving covers. Reduces soil } \\
\text { erosion from highly erodible lands } \\
\text { (HEL), restores wetlands. } \\
\text { Enhances water quality and } \\
\text { wildlife. Annual payment for } \\
\text { enrollment. }\end{array}$ \\
\hline $\begin{array}{l}\text { Nutrient } \\
\text { management }\end{array}$ & $\begin{array}{l}\text { Reducing } \\
\text { fertilizer } \\
\text { application } \\
\text { rate }\end{array}$ & $\begin{array}{l}\text { Reduces nutrient application on } \\
\text { agricultural landscape and } \\
\text { eventually reduces nutrient runoff. }\end{array}$ \\
\hline
\end{tabular}

Agricultural programs in the USA generally allow farmers to choose which programs to participate in, with flexibility to select practices that fit their climate, soils, and, most importantly, management skills (Bernstein et al. 2004). So, in our model, adoption of structural practices, nonstructural practices, nutrient management plans, and enrollment in land retirement are voluntary (Table 2). Each farmer determines whether to participate in land retirement or adopt certain practices 
depending on policy drivers and the farmer's overall objectives. Land retirement programs such as the CRP generally remove land from agricultural production for a long period (at least 10 years) or, in some cases, permanently, for an annual rental fee. Structural practices are eligible for cost-share where farmers receive $50 \%$ of the implementation cost from the federal government as an economic incentive in return for multi-year commitments. When farmers receive economic incentives for structural practice adoption and land retirement enrollment, penalties are levied for noncompliance (Claassen 2012). Because economic incentives are not provided for nonstructural practices and enrollment in nutrient management plans, noncompliance does not incur penalties.

\section{Conservation Practice Adoption Decisions in the Model}

This model focuses on helping understand why some farmers adopt conservation practices and others do not, and how spatial relationships among farmers impact those decisions, with special emphasis on their heterogeneity. At each annual time-step in the model, every farmer agent decides on a land management strategy for conservation practice adoption (Table 2). The decisionmaking algorithm includes net income generated from government programs and agricultural production, the farmers' preferences and land tenure, and influences of their neighbors (summarized below and detailed in Appendix 1).

Every farmer agent in the model uses the same decision algorithm but with different parameters based on the preferences associated with their type. Given these differences, individual agents react differently to the same agricultural policies, including their decision to adopt none or combinations of available practices. A critical variable in the model is land tenure: whether farmers are owners or operators, and whether owners or operators make adoption decisions. Most empirical research concludes that operators control decisions regarding production and adoption of conservation practices on farmland owned by nonoperators (Constance et al. 1996, Soule et al. 2000, Arbuckle 2010); however, we also investigate land tenure dynamics, the possible impact of the growing proportion of farmland owned by nonoperators, and their influence on adoption decisions.

In the ABM, farmers calculate their agricultural income generated from production and collect financial incentives by enrolling in government programs. For agricultural income, farmer agents use Bayesian inference for the expected price and yield from a probability distribution. We represent farmer heterogeneity by setting different parameters for Bayesian updating for different farmer types (Table 1). For example, traditional farmers have more stable price and yield expectations, and business-oriented farmers more likely follow fluctuations in the market because we assume they are more connected to information networks. Farmers' perceptions of crop prices and yields change from year to year. Thus, at the beginning of each year, farmer agents use publicly available price and yield information, their experiences, and their type characteristics to form future price and yield expectations.

Farmer agents also use their social and spatial information networks to evaluate which practices their neighbors adopt. In the model, nonoperators are not initially connected to the information networks, whereas operators (traditional, supplementary, and business-oriented farmers) are connected to both spatial and social networks, and business-oriented farmers have higher network connectedness compared with traditional and supplementary farmers (Daloğlu et al. 2014). As described below, we also test a case in which nonoperator owners increase involvement. Farmer agents' intrinsic environmental attitudes toward each available conservation practice, as reflected by their type (Table 1), also influence their adoption decisions. Based on these variables, the model uses the farmers' decision algorithm to decide which conservation practice to adopt (see Appendix 1).

\section{Land Tenure Changes}

Agricultural land tenure in the USA has undergone critical changes; especially through increases in nonoperator ownership followed by increases in part ownership or full renting (Wunderlich 1993, Duffy 2008). Our study site, the Sandusky watershed, followed these national trends, especially in relation to increased nonoperator ownership (Daloğlu et al. 2014). Studies of the impact of these increases in the Corn Belt region have shown that structural practices are appealing to nonoperators (Petrzelka et al. 2009, Nassauer et al. 2011). However, nonoperator ownership is not defined consistently across studies. Nearly half of Corn Belt farmers are absentee landowners, defined as owners living more than 50 miles from their land (Petrzelka et al. 2009), and land retirement enrollment is lower among absentee landowners compared with other farmers in the Great Lakes Basin (Petrzelka et al. 2009). However, Nassauer et al. (2011) found that one type of nonoperator, investors (defined as landowners who have never farmed), has higher land retirement enrollment rates than other Iowa farmers.

We exploit the difference between these two different studies of different, overlapping subsets of nonoperators as we investigate the impact of changing land tenure dynamics on conservation practice adoption and water quality. In our model, we define absentee landowners and investors as mutually exclusive subtypes of nonoperator owners. Over time, our simulations assume increased involvement of nonoperator owners in conservation decisions (from $0 \%$ to $50 \%$ by the end of the simulation) as they become increasingly connected to information networks over time.

\section{Changes in Agricultural Policy: Crop Revenue Insurance}

Current agricultural policies have numerous drivers for farmers to adopt conservation practices; however, policy incentives frequently outweigh these, resulting in a patchwork of adoption that is not sufficiently effective in improving water quality (Doering et al. 2007). Current Farm Bill discussions include replacement of commodity payments with subsidized crop insurance. Starting in 1985, participation in subsidized crop insurance programs required conservation compliance, i.e., refraining from draining wetlands and implementing a whole farm conservation plan to reduce erosion to acceptable levels. However, in the 1996 Farm Bill, the conservation compliance requirement was removed from the insurance program (Smith and Glauber 1997).

Currently, farmers can choose between two insurance policies, crop yield or revenue insurance, where the USDA provides subsidies for two-thirds of the cost of farmers' premiums (Coble and Barnett 2013). Crop yield insurance protects farmers from the income effects of reduced yield due to weather and other factors, whereas revenue insurance protects farmers' income from 
both yield changes and market fluctuations and indirectly encourages farmers to increase their production area. To evaluate potential impacts of crop insurance replacing commodity payments, we concentrate on revenue insurance (Coble and Barnett 2013).

Numerous studies have investigated the role of risk aversion in adoption of nonstructural practices (conservation tillage and no till) and have consistently found a negative relationship between risk aversion and practice adoption (Bultena and Hoiberg 1983, Belknap and Saupe 1988). Similarly, when farmers consider implementing a nutrient management plan (fertilizer reduction), they generally assume increased yield uncertainty. Providing revenue insurance for farmers reduces the risks involved with nutrient management plan implementation and nonstructural practice adoption (Bosch and Pease 2000).

\section{Plausible Future Scenarios}

The primary goal of this analysis is to understand the drivers of conservation practice adoption and subsequent water quality impacts under plausible futures. For this purpose, we constructed four scenarios by crossing two policy futures with two assumptions about nonoperator owners (Table 3). These scenarios are intended to be prospective and informative rather than projective or prescriptive of the future (Nassauer and Corry 2004).

Table 3. Land management strategies tested under different agricultural policy and structure scenarios

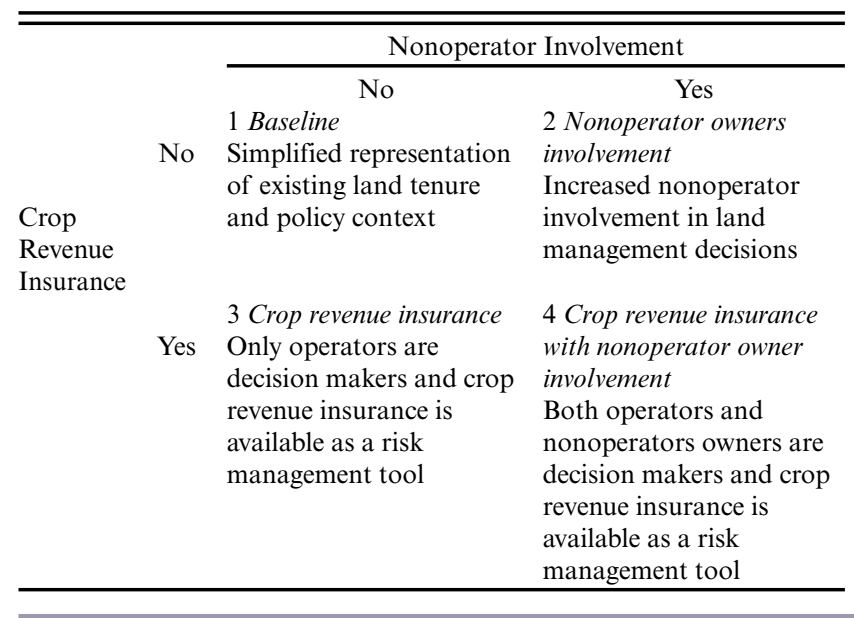

The "Baseline scenario" (1) represents existing land tenure where operators (traditional, supplementary, and business-oriented farmers) are responsible for conservation practice adoption decisions, and nonoperator owners have no involvement in production and conservation decisions. In this scenario, existing crop insurance programs are not included. The "Nonoperator owner involvement scenario" (2) simulates the potential impact of increased involvement of nonoperator owners on the baseline scenario. In this scenario, we assume natural resource agencies and nongovernmental organizations (NGOs) reach out to nonoperator owners and effectively inform them about existing and available conservation practices (Table 4). The "Crop revenue insurance scenario" (3) follows recent U.S. Farm Bill discussions about providing federally subsidized crop revenue insurance rather than commodity production subsidies. This scenario does not assume conservation compliance is required; however, we do explore the alternative below. Here, we assume only operators are decision makers, that they purchase crop revenue insurance at $75 \%$ coverage level for all the land that they manage including the rented land, and that the reduced risk encourages them to increase production area (Table 4). The "Crop revenue insurance with nonoperator owner involvement scenario" (4) explores the impact of increased nonowner involvement on the crop insurance scenario (3). Crop revenue insurance provides a safety net and indirectly motivates both operators and nonoperator owners to increase their production area (Table 4). Cross compliance with conservation programs is also not included in this scenario.

Table 4. Assumptions embedded in scenario simulations

\begin{tabular}{|c|c|}
\hline & Assumptions in the model \\
\hline $\begin{array}{l}\text { Nonoperator } \\
\text { owner } \\
\text { involvement }\end{array}$ & $\begin{array}{l}\text { - When nonoperator owners are involved in the decision } \\
\text { making, the rate of involvement increases from } 0 \% \text { to } \\
\text { eventually reach } 50 \% \text { at the end of the simulation } \\
\text { - Absentee landowners are connected only to the social } \\
\text { network but not to the spatial network because they live } \\
\text { out of the county in which they own land } \\
\text { - Investors who are not absentee landowners are } \\
\text { connected both to the spatial and social network }\end{array}$ \\
\hline $\begin{array}{l}\text { Crop } \\
\text { revenue } \\
\text { insurance }\end{array}$ & $\begin{array}{l}\text { - Farmers buy subsidized crop revenue insurance premium } \\
\text { with } 75 \% \text { coverage level } \\
\text { - Buying crop revenue insurance changes farmers' land } \\
\text { management preferences } \\
\text { - Both nonoperator owners and operators buy crop } \\
\text { revenue insurance for both the land they own and rent. } \\
\text { - Conservation compliance is not linked to crop revenue } \\
\text { insurance } \\
\text { - Rental rates of nonoperator owners reflect the revenue } \\
\text { risk reduction represented by crop revenue insurance }\end{array}$ \\
\hline
\end{tabular}

\section{Water Quality Model-SWAT}

The SWAT is a distributed and spatially explicit continuous-time water quality model at the scale of river basins or watersheds. This model divides watersheds into subbasins with HRUs that represent areas with common land cover and slope and soil properties (Arnold et al. 1998). It is a process-based model of surface hydrology, weather, sedimentation, soil temperature, crop growth, nutrients, pesticides, and groundwater that can simulate the effects of climate and land-use changes on nutrient and sediment delivery from watersheds and is used widely for evaluating and predicting impacts of conservation practices (Arabi et al. 2008). Models created using SWAT have been developed and applied for Lake Erie watersheds to predict potential impacts of conservation practice adoption on water quality (Bosch et al. 2011). More recent SWAT applications indicate that more aggressive strategies than currently employed are needed to substantially reduce nutrient and sediment delivery (Bosch et al. 2013), especially under anticipated future climates (Bosch et al. 2014). .

For this study, we used an existing, higher spatial resolution SWAT model developed for the Sandusky watershed (Daloğlu et al. 2012). The model is employed at a spatial scale in which the 
smallest computational unit of SWAT, average HRU size, corresponds to the average farm size in the Sandusky basin (258 acres; USDA 2009). The model was calibrated and validated with extensive daily observed flow and water quality data for the simulation period (1970-2010) and can be used for future scenario testing. Our previous modeling efforts indicated the importance of weather and farmer management decisions on nutrient delivery especially on DRP runoff (Daloğlu et al. 2012).

Water Quality Impacts of Land Management Strategies

This modeling framework evaluates impacts of farm-scale decisions at the watershed scale. Farmers update their adoption decisions annually during each 41-year simulation; however, because decision-relevant model parameters are sampled from distributions in the decision-making algorithms, each scenario consists of 25 runs, each representing a sampling from the distribution.

We ran the ABM for the 41-year simulation period (1970-2010) to get the landscape management data for the simulation period. We then used that output from the ABM as input to the SWAT and report water quality model output as the average of the 25 SWAT runs over the simulation period (1970-2010) (Figs. 3, 4). Regarding the linkage of ABM and SWAT, for each year, farmers' decisions on conservation practice adoption are used to modify several SWAT input files. Once information on all farmer adoption statuses is updated, the ABM output in the abstract grid file provides the adoption status for every farmer in every period and is used to make the necessary updates in relevant input files of the SWAT in the Sandusky watershed file. Abstract grid cell characteristics are assigned to Sandusky watershed locations by the smallest computational unit of the SWAT, HRUs. The SWAT is then run for the whole simulation period (1970-2010) to provide water quality metrics such as sediment and phosphorus loads. The input files for the SWAT are all in ASCII text format, making it easy to interface with the ABM, and this link is supported with the MatLab programming language. Because ABM results represent adoption statuses for each individual farmer in every period, it is not appropriate to represent the result as averages across multiple simulations. For that reason, results (Figs. 3, 4) are reported as simulation envelopes that contain the results from all 25 simulations. Appendix 2 has further details on how we link $\mathrm{ABM}$ with the SWAT.

\section{RESULTS}

\section{Impacts of Land Tenure Change}

Model results are consistent with observed trends in land tenure (Appendix 1). For example, U.S. agriculture has undergone a structural change of land tenure with a decline in full ownership and an increase in nonoperator ownership and large-scale operations (Wunderlich 1993, Duffy 2008). To represent this, we assume that, after age 65, traditional farmers switch to be nonoperator owners or sell their land to business-oriented or supplementary farmers. This leads to an increase in the percentage of large business-oriented farms and smaller supplementary farms, at the expense of traditional farms (Fig. 3A). We assume supplementary and business-oriented farmers to not change their types as they age. This obviously also leads to an increase in the
Fig. 3. Percentage of farmer types in the total farmer population (A), percentage of nonoperator owners in the total farmer population throughout the simulation period (B). Twenty-five ABM simulation runs fall between two lines of the same color.
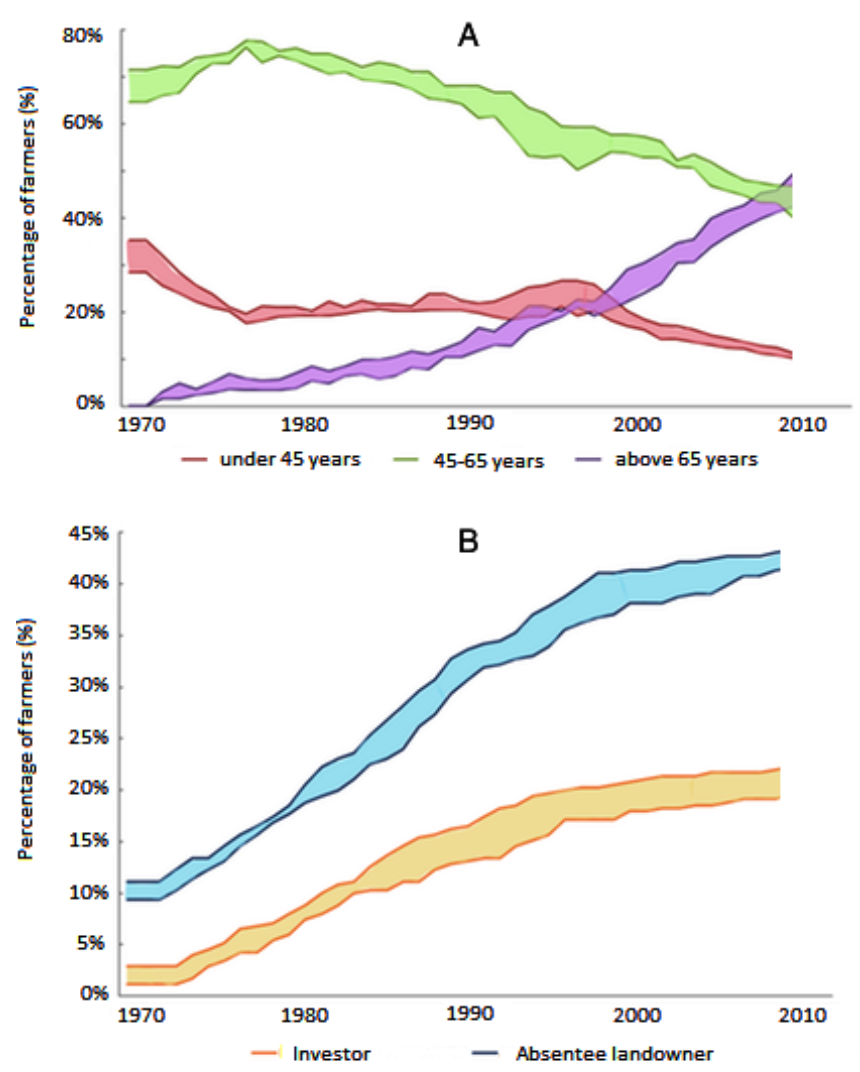

percentage of nonoperator owners among the farmer population (Fig. 3B), as well as production area under their control (Appendix 1 for details).

Because different farmer types have different tendencies toward adoption decisions, as the composition of types changes, the emergent adoption pattern evolves. For example, when nonoperator owners are not involved in decision making and crop revenue insurance is not available (Scenario 1), the percentage of farmers who adopt nutrient management and structural practices shows a significant increase over time, with a more pronounced increase in nutrient management adoption (Fig. 4). Because nonstructural practices, such as no-till technologies were not available until the mid-1980s, these practices were not present in the model until then. Coupled with evolved composition of farmer types, this resulted in a significant increase in adoption over the next 10 years. Land retirement, on the other hand, was minimally adopted, due mostly to the requirement for enrolled land to be retired for 10 years, with penalties for noncompliance (Fig. 4). In Scenario 2, when nonoperator owners take a more active role, they tend to have higher adoption rates for structural 
Fig. 4. Comparison of conservation practice adoption rates under the plausible scenarios such as crop revenue insurance and nonoperator owner involvement in decision making. Twenty-five ABM simulation runs fall between two lines of the same color.
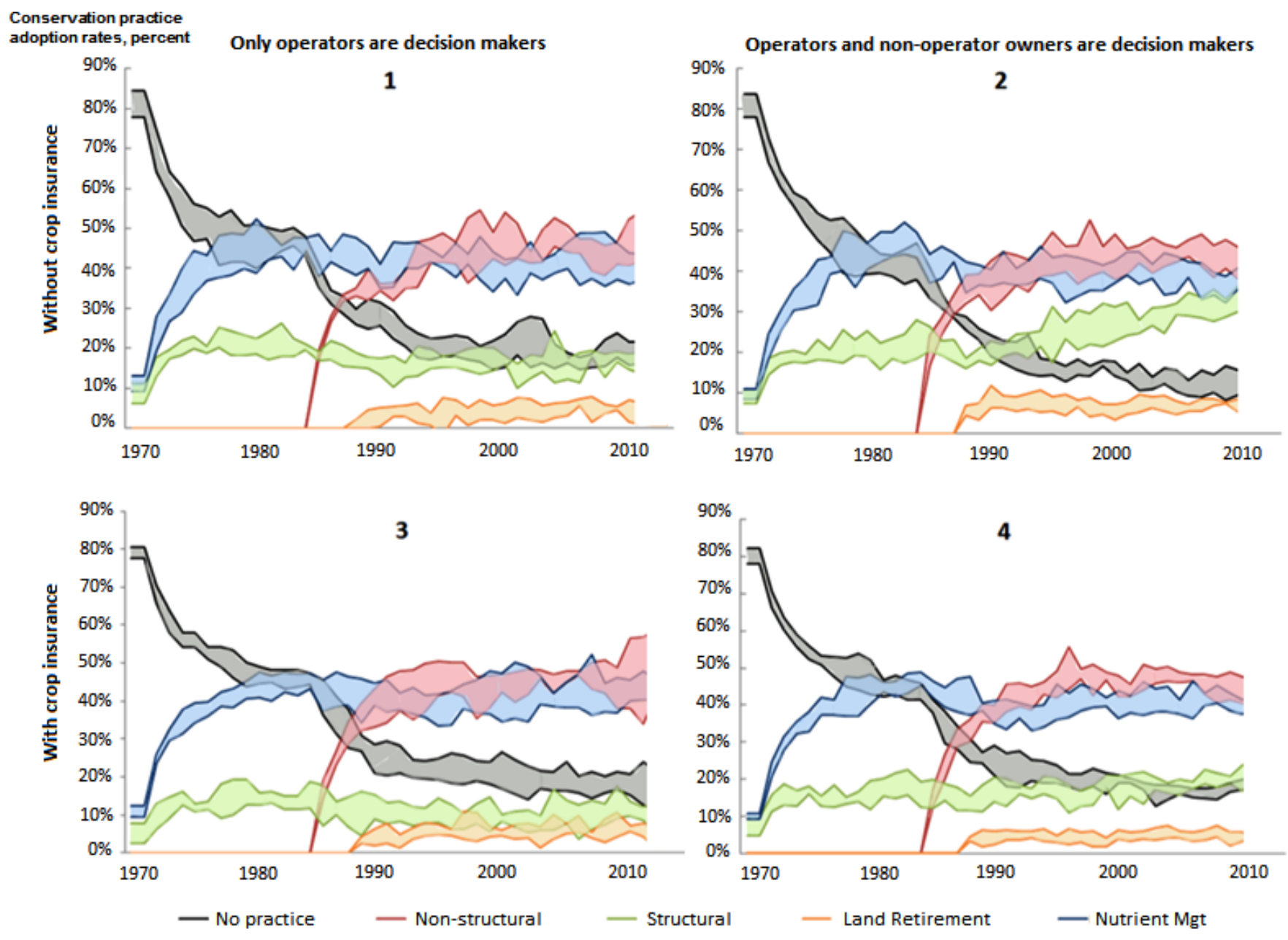

practices and land retirement. Average adoption rate for structural practices increased from $17 \%$ to $23 \%$ when nonoperators are active decision makers (Fig. 4).

\section{Impacts on Water Quality}

In Scenario 2, by the end of the simulation period, $50 \%$ of the nonoperator owners are the decision makers for conservation practice adoption (Table 4). The positive attitudes of nonoperator owners toward conservation practices results in higher adoption rates for structural practices and enrollment in land retirement programs reducing TP loads (Figs. 5, 6). In Scenario 2 , results for sediment, organic P (OrgP), and DRP load are similar, with the improvement more pronounced for sediment because nonoperator owners favor structural practices, which are more effective in reducing the sediment load.

\section{Impacts of Agricultural Policy Change}

Options under consideration for the U.S. Farm Bill include replacing commodity payments with subsidized crop revenue insurance premiums to create stronger incentives for farmers to enroll in crop revenue insurance. In these simulations, conservation
Fig. 5. Comparison of average annual total phosphorus (TP) load in kilograms for Scenarios 1-4 representing the average of 25 ABM simulations linked to SWAT. Whiskers show minimum and maximum values, whereas the box shows 25,50 , and 75 percentiles.

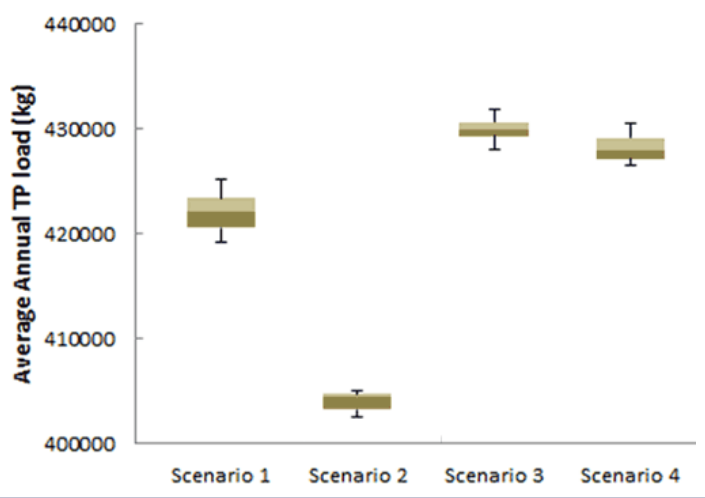


Fig. 6. Comparison of Baseline, Scenario 1, with Scenarios 2, 3, and 4 in terms of sediment, organic phosphorus (OrgP), dissolved reactive phosphorus (DRP), and total phosphorus (TP) loads, representing the average of $25 \mathrm{ABM}$ simulations linked to SWAT.

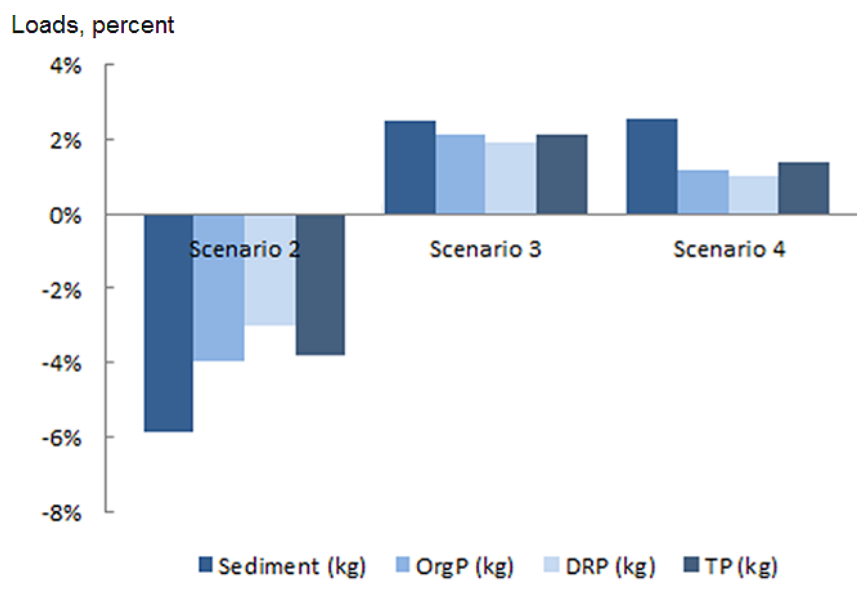

compliance is not required for crop revenue insurance enrollment. The effects of the insurance program can be seen by comparing Scenarios 1 and 3 (Table 3). The insurance protects farmers from both market and crop yield fluctuations, and because the payments are based on production area, farmers appear encouraged to increase their production area. Under this scenario, nutrient management plans increase, followed by a steep increase in nonstructural practices when these practices become available (Fig. 4). When crop revenue insurance premiums are subsidized, structural practice adoption and land retirement enrollment rates decrease both for operators and nonoperator owners, whereas enrollment in nutrient management plans increase. The ABM results also indicate a decrease in land retirement and structural practices regardless of the nonoperator owner involvement (Scenarios 3 and 4), which leads to a more homogenous conservation landscape (Fig. 4). With subsidized crop revenue insurance, average TP, OrgP, DRP, and sediment loads are higher (Figs. 5, 6), primarily due to the reduction in structural practices and land retirement.

However, a moral hazard can result if farmers use crop insurance as an incentive to underfertilize their crops to receive indemnities (Sheriff 2005) or to introduce practices or enterprises that they might avoid without crop insurance, i.e., planting corn or soybeans where adequate seasonal rainfall is uncertain. Goodwin and Smith (2003) also raised concerns about crop insurance and other disaster relief programs discouraging land retirement. Another criticism is the potential of supporting an increase in production on erodible land (Keeton et al. 2000).

\section{Modifications in Agricultural Policy: Closing the SES Model Loop}

In our modeling framework, we built plausible scenarios that follow the latest U.S. Farm Bill discussions of providing federally subsidized crop revenue insurance rather than commodity production subsidies (Scenario 3) and assumed conservation compliance is not tied to crop revenue insurance (Stubbs 2012).
The model results suggest slightly higher TP, OrgP, DRP, and sediment yields (Fig. 6) under this scenario compared with the baseline (Scenario 1), attributed to the reduction in structural practice and land retirement enrollment (Fig. 4).

To close the loop in the SES model where social and environmental systems have reciprocal feedbacks, we add a policy modification step and allow farmer agents to respond to the new set of incentives, sanctions, and regulations. For this purpose, we linked conservation compliance to crop revenue insurance and evaluated different conservation compliance definitions. There have been discussions of strengthening and expanding conservation compliance requirements (Perez 2007, American Farmland Trust 2011, Cox et al. 2011). So, in our framework, we tested three conservation compliance definitions where farmers can; (a) adopt nonstructural practices; (b) implement structural practices; or (c) choose either nonstructural or structural practices (Table 5). Although the U.S. General Accounting Office (GAO 2003) has emphasized that compliance enforcement needs updating and upgrading, we assume $100 \%$ adherence to conservation compliance.

We observe higher nutrient runoff; especially the bioavailable DRP when farmers choose nonstructural practices as conservation compliance requirements (Fig. 7), a common practice for economic reasons. However, if conservation compliance requirements are expanded to include nutrient management with a focus on promoting structural practices, linked model results indicate the effectiveness of structural practices in reducing nutrient delivery from agricultural landscapes (Fig. 7).

\section{POLICY IMPLICATIONS}

This framework provides a powerful tool to explore the impacts of plausible futures such as changes in the agricultural land tenure and policy on adoption of conservation practices. Our linked model distinguishes among nutrient management plans that reduce fertilizer application, nonstructural practices such as conservation and no-till, structural practices such as filter strips to trap soil particles and nutrients, and land retirement programs. Importantly, this model shows that changes in land tenure and crop insurance policy affect adoption of these practices, altering the agricultural landscape and affecting water quality.

Sandusky Watershed represents a typical watershed of the Corn Belt region. Therefore, the conclusions of the study are relevant for other Corn Belt watersheds. However, differences in locationspecific environmental drivers and processes such as land cover, soil type, and climatic conditions, and their effects on the transformation of $\mathrm{N}$ and $\mathrm{P}$ need consideration.

By investigating the water quality impacts of four plausible scenarios, we demonstrate the importance of the understudied nonoperator owners and the possible effects of new policies related to crop revenue insurance. Our results indicate maximum load reductions, especially sediment load reductions, occur when nonoperator owners are involved in the decision-making process and when crop revenue insurance is not offered in lieu of commodity payments tied to compliance (Scenario 2). This improvement is mainly attributed to the increase in the percentage of farmers who favor structural practices, which are more effective in reducing sediment and nutrient load. Our results also point to 
Fig. 7. Change in water quality metrics when conservation compliance is linked to crop revenue insurance programs as a requirement.

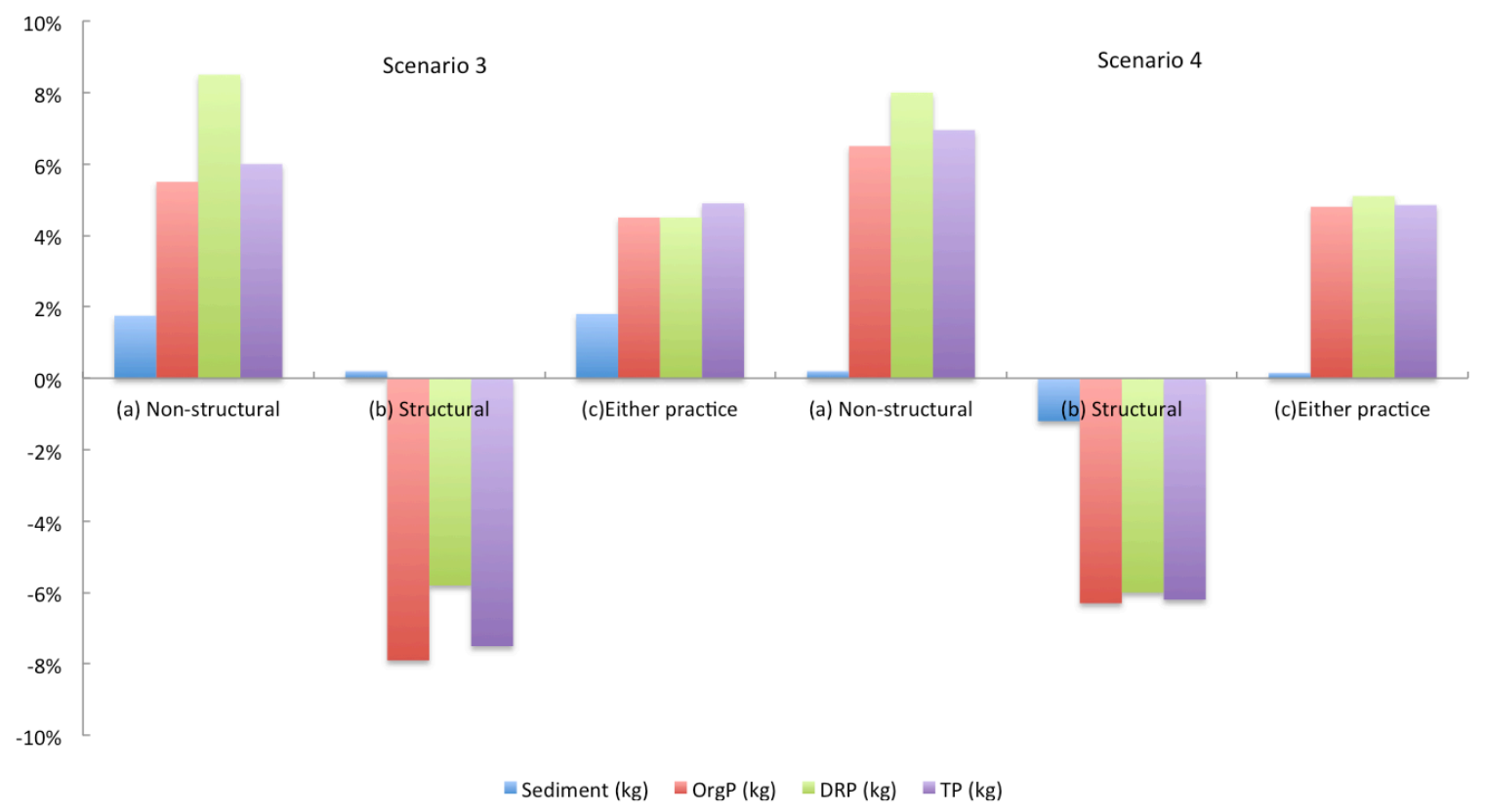

the positive influence of nonoperator owner involvement and highlight the importance of devising innovative policies to reach out and inform nonoperator owners about the existing water quality problems, possible solutions, and their role in implementing them.

When subsidized crop revenue insurance is promoted as a risk management program, in the absence of conservation compliance, it incentivizes farmers, regardless of type, to increase production area, even including areas that are highly erodible or wetlands. This then results in a more homogenous conservation landscape that yields slightly higher loads (Scenarios 3 and 4) due to a decrease in structural practices and land retirement enrollment. In contrast, our results show that if crop revenue insurance is tied to conservation, particularly structural practices, sediment and nutrient loads decrease. A recent survey of Iowa farmers reveals support for expanding conservation compliance requirements to include nutrient management as well as erosion control (Arbuckle 2010). Moreover, because structural practices are visible by remote sensing, compliance enforcement would require fewer NRCS personnel and less federal budget.

Our analyses show only modest load reduction (1-6\%) under the plausible future scenarios, which is comparable to other relevant applications of the SWAT that assume feasible levels of implementation (Arabi et al. 2008, Bosch et al. 2013). The adoption rates of conservation practices are also consistent with the observations (Smith and Goodwin 1996, Bosch and Pease 2000, Goodwin and Smith 2003, Duffy 2008, Petrzelka et al. 2009, Nassauer et al. 2011) and feasible levels of implementation used by other SWAT models (Arabi et al. 2008, Bosch et al. 2013). Collectively, these results point to the need for innovative policies that promote greater adoption of conservation practices and for attaching conservation compliance to crop revenue insurance with perhaps new definitions of conservation compliance. Indeed, previous SWAT models implemented in the Lake Erie Basin indicate up to $30-40 \%$ yield reduction effectiveness with significantly increased adoption rates (Bosch et al. 2013).

Responses to this article can be read online at: http://www.ecologyandsociety.org/issues/responses. php/6597

Acknowledgments:

We thank Kyung Hwa Cho for his consultation regarding model building. This work was supported in part by Graham Environmental Sustainability Institute Doctoral Fellowship program, NSF \# DBI-1052875 to the National Socio-Environmental Synthesis Center) grant to J. Nassauer, and NOAA Center for Sponsored Coastal Ocean Research grant NA07OAR432000 to D. Scavia. Ecofore Lake Erie publication 13-006.

\section{LITERATURE CITED}

American Farmland Trust. 2011. Conservation compliance: safeguarding environmentally sensitive farm and ranch land. American Farmland Trust. [online] URL: http://www. farmbillfacts.org/wp-content/uploads/2013/01/AFT_FB_SafeGuard_2013. pdf

Arabi, M., J. R. Frankenberger, B. A. Enge, and J. G. Arnold. 2008. Representation of agricultural conservation practices with SWAT. Hydrological Processes 22(16):3042-3055. 
Arbuckle, J. G. 2010. Rented land In Iowa: social and environmental dimensions. Iowa State University Extension, Centerville, Iowa, USA.

Arnold, J. G., R. Srinivasan, R. S. Muttiah, and J. R. Williams. 1998. Large area hydrologic modeling and assessment - Part 1: Model development. Journal of the American Water Resources Association, 34(1), 73-89.

Axelrod, R. M. 1997. The complexity of cooperation: agent-based models of competition and collaboration. Princeton, N.J.: Princeton University Press.

Belknap, J., and W. E. Saupe. 1988. Farm Family Resources and the Adoption of No-Plow Tillage in Southwestern Wisconsin. North Central Journal of Agricultural Economics, 10(1), 13-23.

Bernstein, J., J. Cooper, and R. Claasen. 2004. Agriculture and the environment in the United States and EU. Economic Research Service, USDA, Washington, D.C., USA.

Bosch, N. S., J. D. Allan, D. M. Dolan, H. Han, and R. P. Richards. 2011. Application of the soil and water assessment tool for six watersheds of Lake Erie: model parameterization and calibration. Journal of Great Lakes Research 37(2):263-271.

Bosch, N. S, J. D. Allan, J. P. Selegean, and D. Scavia. 2013. Scenario-testing of agricultural best managent practices in Lake Erie watersheds. Journal of Great Lakes Research 39:429-436.

Bosch, N. S., M. A. Evans, D. Scavia, and J. D. Allan. 2014. Interacting effects of climate change and agricultural BMPs on nutrient runoff. Journal of Great Lakes Research: in press.

Bosch, D. J., and J. W. Pease. 2000. Economic risk and water quality protection in agriculture. Review of Agricultural Economics 22(2):438-463.

Boyer, E. W., C. L. Goodale, N. A. Jaworsk, and R. W. Howarth. 2002. Anthropogenic nitrogen sources and relationships to riverine nitrogen export in the northeastern USA. Biogeochemistry 57(1):137-169.

Broussard, W. P., R. E. Turner, and J. V. Westra. 2012. Do federal farm policies influence surface water quality? Agriculture Ecosystems and Environment 158:103-109.

Bultena, G. L., and E. O. Hoiberg. 1983. Factors affecting farmers adoption of conservation tillage. Journal of Soil and Water Conservation 38(3):281-284.

Carpenter, S. R. 2008. Phosphorus control is critical to mitigating eutrophication. Proceedings of the National Academy of Sciences of the United States of America 105(32):11039-11040. doi: 10.1073/pnas.0806112105 http://dx.doi.org/10.1073/pnas.0806112105

Claassen, R. 2012. The future of environmental compliance incentives in U.S. agriculture: the role of commodity, conservation, and crop insurance programs. EIB-94, U.S. Department of Agriculture, Economic Research Service, Washington, D.C., USA.

Coble, K. H., and B. J. Barnett. 2013. Why do we subsidize crop insurance? American Journal of Agricultural Economics 95 (2):498-504.
Constance, D. H., J. S. Rikoon, and J. C. Ma. 1996. Landlord involvement in environmental decision-making on rented Missouri cropland: pesticide use and water quality issues. Rural Sociology 61 (4):577-605.

Cox, C., A. Hug, and N. Bruzelius. 2011. Losing ground. The Environmental Working Group, Washington, D.C., USA.

Daloğlu, I., K. H. Cho, and D. Scavia. 2012. Evaluating causes of trends in long-term dissolved reactive phosphorus loads to Lake Erie. Environmental Science and Technology 46(19):10660-10666.

Daloğlu, I., J. I. Nassauer, R. L. Riolo., and D. Scavia. 2014. Adoption of conservation practices: an agent based modeling typology of farmer characteristics. Agricultural Systems: in press.

Doering, O. C. K., C. L., J. I. Nassauer, and D. Scavia. 2007. Agricultural policy choices. Pages 285-301 in J. I. S. Nassauer, M. V., and D. Scavia, editors. From the corn belt to the Gulf: societal and environmental implications of alternative agricultural futures. Resources for the Future, Washington, D.C., USA.

Dolan, D. M., and S. C. Chapra. 2012. Great Lakes total phosphorus revisited: 1. Loading analysis and update (1994-2008). Journal of Great Lakes Research 38(4):730-740.

Duffy, M. 2008. Farmland tenure and ownership in Iowa 2007. Iowa State University Extension, Centerville, Iowa, USA.

Forster, D. L. 2000. Public policies and private decisions: their impacts on Lake Erie water quality and farm economy. Journal of Soil and Water Conservation 55(3):309-322.

Galloway, J. N., F. J. Dentener, D. G. Capone, E. W. Boyer, R. W. Howarth, S. P. Seitzinger, G. P. Asner, C. C. Cleveland, P. A. Green, E. A. Holland, D. M. Karl, A. F. Michaels, J. H. Porter, A. R. Townsend, and C. J. Vöosmarty. 2004. Nitrogen cycles: past, present, and future. Biogeochemistry 70(2):153-226.

General Accounting Office (GAO). 2003. Agricultural conservation USDA needs to better ensure protection of highly erodible cropland and wetlands: report to the ranking Democratic member, Committee on Agriculture, Nutrition, and Forestry, U.S. Senate. U.S. General Accounting Office, Washington, D.C., USA. URL: http://purl. access.gpo.gov/GPO/LPS36719.

Goodwin, B. K., and V. H. Smith. 2003. An ex post evaluation of the conservation reserve, federal crop insurance, and other government programs: program participation and soil erosion. Journal of Agricultural and Resource Economics 28(2): 201.

Grimm, V., U. Berger, D. L. De Angelis, J. G. Polhill, J. Giske, and S. F. Railsback. 2010. The ODD protocol: a review and first update. Ecological Modelling 221(23):2760-2768.

Hawley, N., T. H. Johengen, Y. R. Rao, S. A. Ruberg, D. Beletsky, S. A. Ludsin, and S. B. Brandt. 2006. Lake Erie hypoxia prompts Canada-U.S. study. Eos, Transactions of the American Geophysical Union 87(32):313-319. [online] URL: http://www.glerl.noaa.gov/ ifyle/docs/hawley-eos-06.pdf

Janssen, M. 1998. Use of complex adaptive systems for modeling global change. Ecosystems 1(5):457-463. [online] URL: http://dlc. dlib.indiana.edu/dlc/bitstream/handle/10535/2630/use_of_complex. pdf?sequence $=1$ 
Keeton, K., J. Skees, and J. Long. 2000. The potential influence of risk management programs on cropping decisions at the extensive margin. Staff manuscript, Department of Agricultural Economics, University of Kentucky, Lexington, Kentucky, USA.

Levin, S., T. Xepapadeas, A.-S. Crépin, J. Norberg, A. de Zeeuw, C. Folke, T. Hughes, K. Arrow, S. Barrett, G. Daily, P. Ehrlich, N. Kautsky, K.-G. Maler, S. Polasky, M. Troell, J. R. Vincent, and B. Walker. 2012. Social-ecological systems as complex adaptive systems: modeling and policy implications. Environment and Development Economics 18:(2):1111-132.

Liu, J. G., T. Dietz, S. R. Carpenter, M. Alberti, C. Folke, E. Moran, A. N. Pell, P. Deadman, T. Kratz, J. Lubchenco, E. Ostrom, Z. Ouyang, W. Provencher, C. L. Redman, S. H. Schneider, and W. W. Taylor. 2007. Complexity of coupled human and natural systems. Science 317(5844):1513-1516.

Michalak, A. M., E. J. Anderson, D. Beletsky, S. Boland, N. S. Bosch, T. B. Bridgeman, J. D. Chaffin, K. H. Cho, R. Confesor, I. Daloğlu, J. DePinto, M. A. Evans, G. L. Fahnenstiel, L. He, J. C. Ho, L. Jenkins, T. Johengen, K. C. Kuo, E. Laporte, X. Liu, M. McWilliams, M. R. Moore, D.J. Posselt, R. P. Richards, D. Scavia, A. L. Steiner, E. Verhammer, D. M. Wright, and M. A. Zagorski. 2013. Record-setting algal bloom in Lake Erie caused by agricultural and meteorological trends consistent with expected future conditions. Proceedings of the National Academy of Sciences of the United States of America 110(16):6448-6652. http://dx.doi.org/10.1073/pnas.1216006110

Monticino, M., M. Acevedo, B. Callicott, T. Cogdill, and C. Lindquist. 2007. Coupled human and natural systems: a multiagent-based approach. Environmental Modelling and Software 22 (5):656-663.

Nassauer, J. I., and R. C. Corry. 2004. Using normative scenarios in landscape ecology. Landscape Ecology 19(4):343-356.

Nassauer, J. I., J. A. Dowdell, Z. Wang, D. McKahn, B. Chilcott, C. L. Kling, and S. Secchi. 2011. Iowa farmers' responses to transformative scenarios for Corn Belt agriculture. Journal of Soil and Water Conservation 66(1):18a-24a. http://dx.doi.org/10.2489/ jswc.66.1.18A

National Research Council (U.S.) Committee on Twenty-First Century Systems Agriculture. 2010. Toward sustainable agricultural systems in the 21 st century. National Academies Press, Washington, D.C., USA.

Neitsch, S. L., J. G. Arnold, J. R. Kiniry, and J. R. Williams. 2011. Soil and water assessment tool (SWAT) theoretical documentation. Texas A\&M University, College Station, Texas, USA.

Perez, M. 2007. Trouble downstream: upgrading conservation compliance. Environmental Working Group, Washington, D.C., USA.

Petrzelka, P., T. Buman, and J. Ridgely. 2009. Engaging absentee landowners in conservation practice decisions: a descriptive study of an understudied group. Journal of Soil and Water Conservation 64(3):94a-99a.

Rammel, C., S. Stagl, and H. Wilfing. 2007. Managing complex adaptive systems - a co-evolutionary perspective on natural resource management. Ecological Economics 63(1):9-21.
Ribaudo, M.O., and M. Smith, M. 2000. Water quality: impacts of agriculture. In AH-722. Agricultural Resources and Environmental Indicators. Economic Research Service, USDA, Washington, D.C., USA.

Robinson, D. T., D. Murray-Rust, V. Rieser, V. Milicic, and M. Rounsevell. 2012. Modelling the impacts of land system dynamics on human well-being: using an agent-based approach to cope with data limitations in Koper, Slovenia. Computers Environment and Urban Systems 36(2):164-176.

Scavia, D., J. D. Allan, K. K. Arend, S. Bartell, D. Beletsky, N. S. Bosch, S. B. Brandt, R. D. Briland, I. Daloğlu, J. V. DePinto, D. M. Dolan, M. A. Evans, T. M. Farmer,D. Goto, H. Han, T. O. Höök, R. Knight, S. A. Ludsin, D. Mason, A. M. Michalak, R. P. Richards, J. J. Roberts, D. K. Rucinski, E. Rutherford, D. J. Schwab, T. Sesterhenn, H. Zhang, and Y. Zhou. 2014. Assessing and addressing the re-eutrophication of Lake Erie: central basin hypoxia. Journal of Great Lakes Research 40(2):226-246.

Sharpley, A. N., S. C. Chapra, R. Wedepohl, J.T. Sims, T. C. Daniel, and K. R. Reddy. 1994. Managing agricultural phosphorus for protection of surface waters-issues and options. Journal of Environmental Quality 23(3):437-451.

Sheriff, G. 2005. Efficient waste? Why farmers over-apply nutrients and the implications for policy design. Review of Agricultural Economics 27(4):542-557.

Smith, V. H., and J. W. Glauber. 1997. The effects of the 1996 farm bill on feed and food grains. Trade Research Center, Montana State University, Bozeman, Montana, USA.

Smith, V. H., and B. K. Goodwin. 1996. Crop insurance, moral hazard, and agricultural chemical use. American Journal of Agricultural Economics 78:428-438.

Soule, M. J., A. Tegene, and K. D. Wiebe. 2000. Land tenure and the adoption of conservation practices. American Journal of Agricultural Economics 82(4):993-1005.

Stubbs, M. 2012. Conservation compliance and U.S. farm policy. Congressional Research Service Reports R42459. U.S. Congress, Washington, D.C., USA.

United States Department of Agriculture. 2009. 2007 Census of Agriculture. Volume 1, Part 51, Geographic area series. United States summary and state data. U.S. Department of Agriculture, Washington, D.C., USA.

Valbuena, D., P. H. Verburg, and A. K. Bregt. 2008. A method to define a typology for agent-based analysis in regional land-use research. Agriculture Ecosystems and Environment 128(1-2):2736 .

Veldkamp, A., and P. H. Verburg. 2004. Modelling land use change and environmental impact. Journal of Environmental Management 72(1-2):1-3.

Wunderlich, G. 1993. Land ownership and taxation in American agriculture. Westview Press, Boulder, Colorado, USA.

Zhou, Y., D. R. Obenour, D. Scavia, T. H. Johengen, and A. M. Michalak. 2013. Spatial and temporal trends in Lake Erie hypoxia, 1987-2007. Environmental Science and Technology 47 (2):899-905. http://dx.doi.org/10.1021/es303401b 


\section{Appendix 1:Model parameters for the agent-based model of farmer adoption of conservation practices}

The following sections present the model used in this study following the ODD (Overview, Design concepts and Details) protocol (Grimm et al. 2006; Grimm et al., 2010).

\section{Purpose}

This model is designed to investigate the impact of alternative policy approaches and changing land tenure dynamics on farmer adoption of conservation practices intended to increase the water quality.

\section{State variables and scales}

The modeled environment consists of a two-dimensional grid space representing the abstract agricultural landscape of the Sandusky watershed. The ABM is coupled with a water quality model; therefore the specifics of the water quality model are taken into consideration during the setup phase of the ABM. For a better match with the water quality model, there are 351 farmers in the ABM. The model is run for annual steps of 41 years (1970-2010). Figure 1-1 shows the class diagram of the model.

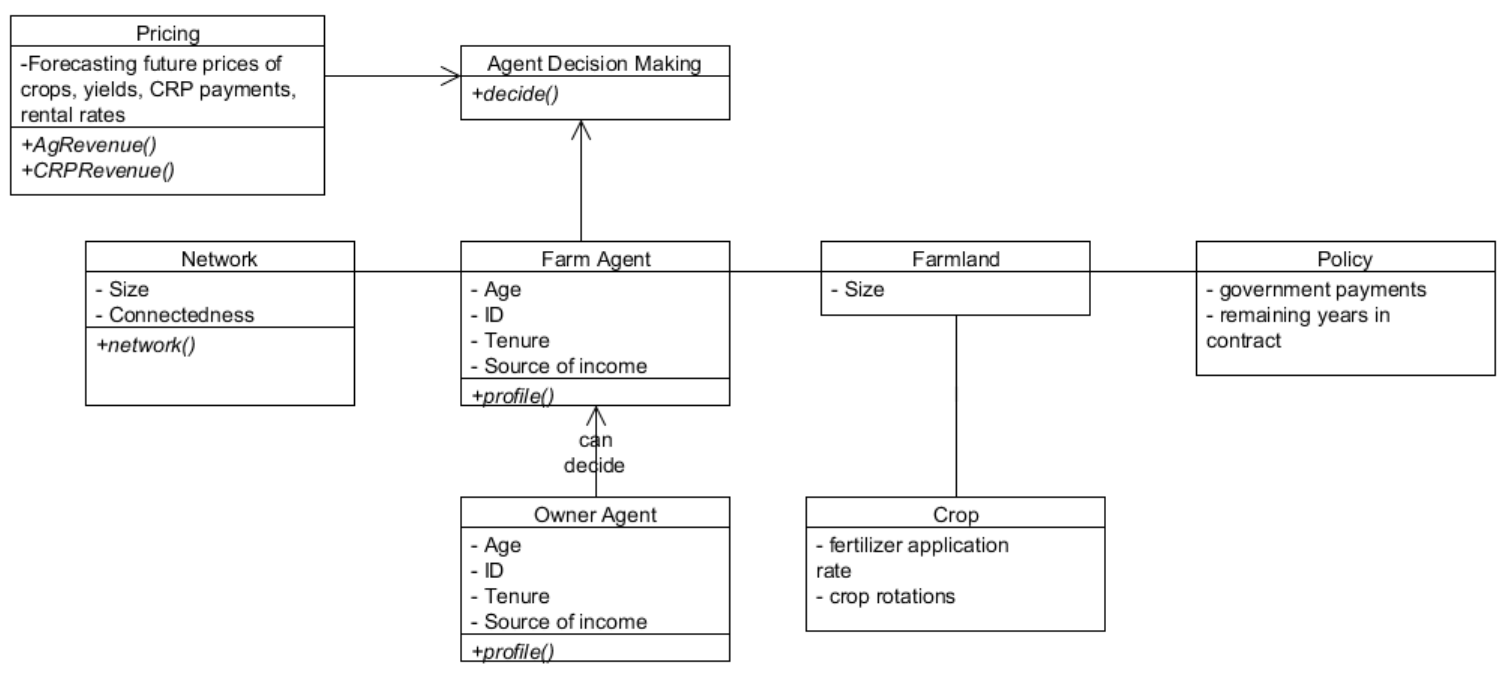

Figure 1-1: Class diagram of the ABM model

In the model, every farmer owns a farm and each has utility functions with bounded rationality. The farmers specialize in cash-crops such as corn, soybean or winter wheat. They have cash earnings from crop production or from enrollment in government programs. The 
farmers have different land areas, crop yields, and future crop price and yield expectations. The farmers also maintain network connections to other farmers and government agencies with varying strengths. In most $\mathrm{ABMs}$, agents are defined by their spatial location (Brown et al. 2005); however, in this model the farmer agents do not change their location as time progresses. A farmer's location on the grid determines the spatial neighbors of that farmer. Some of the farmer attributes do not change during the simulations, such as the percentage of income derived from farming and connectedness to the network. However, as farmers age in every simulation run, some of them change their types. For example, after age 65 some of the traditional farmers leave the farming business and switch to be non-operator owners, or sell/rent their land to business-oriented or supplementary farmers. We assume supplementary and business-oriented farmers to not change their types as they age. This obviously also leads to an increase in the percentage of non-operator owners among the farmer population (Figure 3B, main text), as well as production area under their control (Figure 1-2).

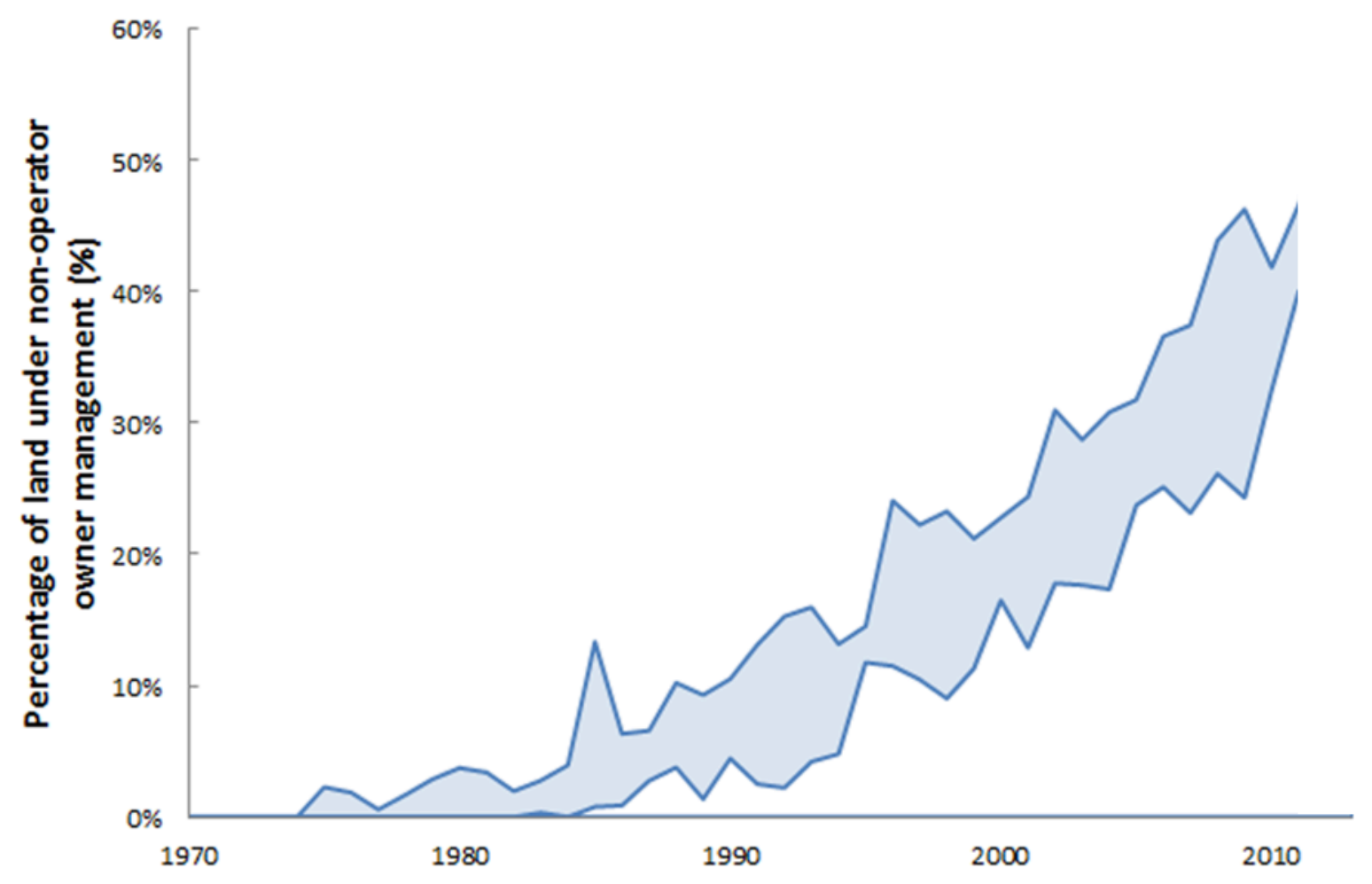

Figure 1-2: Percentage of land under non-operator owners' control increases. 25 ABM simulation runs fall between two lines of the same color.

\section{Process overview and scheduling}

The diagram in Figure 1-3 gives the process overview and scheduling of the model. For each simulation, farmers annually update their adoption decisions under the influence of agricultural

44 policy, changing land tenure dynamics, their preferences, and their neighbors' decisions. The 
agent loop is equally important as the landscape update, which is the key mechanism that affects the water quality component of the coupled system (Figure 1-3).

During the simulation phase, each farmer agent is provided with a behavioral model that guides the decision-making process. With the behavioral model and farmer attributes, the farmer agents decide whether to adopt a specific conservation practice or not. The results from the farmer agent decision update the management landscape.

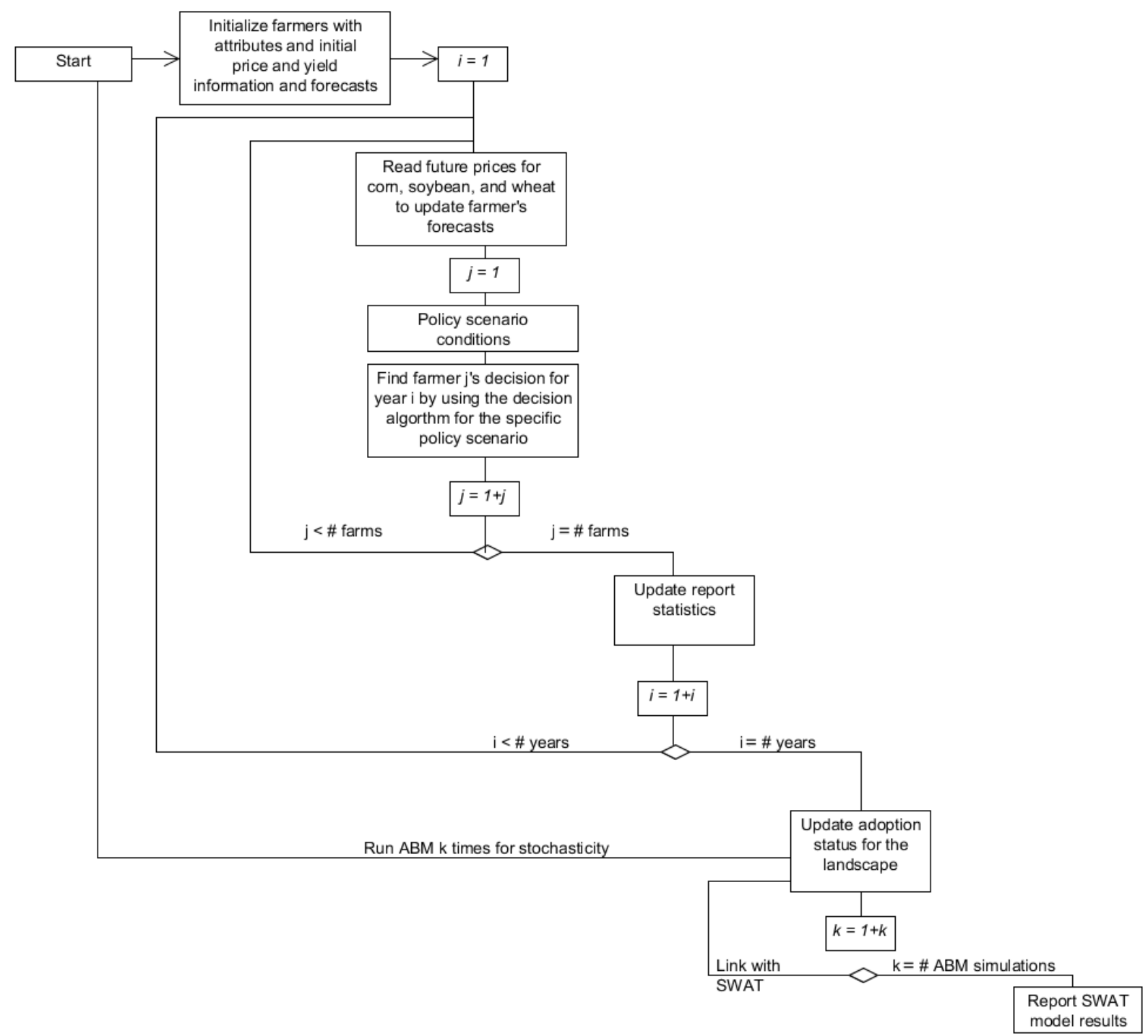

Figure 1-3: Process overview and scheduling for a model run.

The decision-making algorithm consists of inputs from profit generated from the agricultural activity, enrollment in government programs, the farmer preferences for conservation practices depending on farmer type, and sometimes information from their spatial neighbors and other farmers in their social network. Every agent in the model uses the same decision algorithm with 
arrangements, decision makers could either be the owner or the tenant. Because of this flexibility, this model is also used to investigate the possible impact of growing proportions of farmland owned by non-operator owners and their influence on conservation decisions.

\section{Design Concepts}

- Emergence: The agricultural landscape of conservation practices emerges from the and spatial networks, preferences, and policies that they follow.

- Adaptation: Farmers adapt and update their decisions depending on price and yield expectations for future years. Depending on their types, farmers have differing network connectivity, which influences their conservation decisions. Farmers update their conservation practice adoption decisions by interacting and observing other farmers and due to changes in the agri-environmental policies and markets.

- Prediction: Farmers have expectations for future yields, crop prices, and rental rates offered for land retirement programs by using the historic information. Farmers use these forecasts for their adoption decisions every year.

- Sensing: Farmers know their production yields every year and their profit from that year's production. Farmers also know whether their neighbors, both in their spatial and social networks, adopted a practice.

- Interaction: Farmers interact to exchange information on adoption of conservation practices. Every farmer type has varying network strength and connectivity.

- Stochasticity: The model has stochasticity built in several ways. Conservation practice selection decision is stochastic, as the farmers are most likely to select the highest ranked practice. However, as the farmers are not modeled as purely rational decision makers, the highest ranking conservation practice is not always chosen. Moreover, to better represent the decision environment, the submodels also have stochastic parameters to represent the uncertainty and variability observed in nature. By using the agent decision-making algorithm over the model run of 41 years, each agent has a sequence of conservation practices adopted and resultant landscape changes.

- Collectives: Farmers are connected in two ways. In the spatial networks, farmers are connected to their immediate spatial neighbors. In social networks, farmers are connected to other farmers with varying strengths and connectivity. Network connections allow farmers to observe whether other farmers in their network have adopted a conservation practice.

- Observation: The model produces the conservation adoption patterns at the end of each simulation.

- Learning: Bayesian inference used for updating price and yield expectations of farmers is a form of learning.

\section{Initialization}

At the beginning of each model simulation, 351 farmers are created to represent the total of approximately 7500 farmers in the Sandusky watershed. Because the ABM is linked to SWAT, properties of SWAT are decisive. In SWAT, there are 351 agricultural HRUs, smallest computation components; therefore in ABM we have 351 agents. The initial agent characteristics are given in Table 1-1. The farmer typology built in Daloğlu et al. (2014) informs the farmer preferences for conservation practices typologically. 
The agricultural structure of the study area is defined by the number of farmers and their 105 production areas. The parameters defining each farmer such as age, ownership of the land, 106 percentage of income generated by agricultural activity, and land tenure arrangements are 107 assigned from a normal distribution within a range that is informed by regional statistics 108 provided by National Agricultural Statistics Service (NASS). Then, each farmer agent is 109 associated with its appropriate type (Table 1-2). 


\begin{tabular}{llc}
\hline Property & Meaning & The Model \\
\hline Reactive & Responds to changes in the environment & Yes \\
Autonomous & Have control over its own actions & Yes \\
Temporally continuous & Continuous agent behavior & Yes \\
Communicative & Communicates with other agents & Yes \\
Mobile & Changes location from one to another & No \\
Flexible/Learning & Actions are not scripted, can change & Yes \\
Character & Believable personality with emotions & No \\
Interactive physically & Decisions affect other agents & Yes \\
Interactive socially & Decisions affect other agents & Yes \\
Goal oriented & Responsive to the environment & Yes
\end{tabular}

Table 1-1: Farmer agent properties

Farmer types

\begin{tabular}{ccccc}
\hline $\begin{array}{l}\text { Policy-relevant } \\
\text { farmer characteristics }\end{array}$ & Traditional & $\begin{array}{c}\text { Supplement } \\
\text { ary }\end{array}$ & $\begin{array}{c}\text { Business } \\
\text {-oriented }\end{array}$ & $\begin{array}{c}\text { Non- } \\
\text { operator } \\
\text { owners }\end{array}$ \\
\hline Land Tenure & Full owner & $\begin{array}{c}\text { Full/Part } \\
\text { owner }\end{array}$ & $\begin{array}{c}\text { Part } \\
\text { owner } \\
\text { Medium } \\
\text { to Large }\end{array}$ & $\begin{array}{c}\text { Non- } \\
\text { operator owner }\end{array}$ \\
$\begin{array}{c}\text { Primary Source of } \\
\text { Income } \\
\text { Information }\end{array}$ & Small & Small & Noffarm & Off-farm \\
Networks & $\begin{array}{c}\text { Ooderately } \\
\text { connected }\end{array}$ & $\begin{array}{c}\text { Moderately } \\
\text { connected }\end{array}$ & $\begin{array}{c}\text { Most } \\
\text { connected }\end{array}$ & $\begin{array}{c}\text { Off-farm } \\
\text { connected }\end{array}$
\end{tabular}

Table 1-2: Farmer types constructed by using policy-relevant farmer characteristics.

113 Input

114 In every simulation run, the model reflects changes in the political and economic 115 environment such as changes in agricultural policy and crop prices.

\section{Submodels}

117 Farmers are autonomous decision makers regarding conservation practice adoption. Below 118 are the sub-model explanations that control farmers' adoption decisions. The algorithm includes 119 subcomponents that model the profitability of the farm business, influence of farmer preferences, 120 and connectedness of the farmers, both socially and spatially. A special attention is given to 121 agricultural profit calculations and the social connectedness of the agents, as they play significant 122 roles in agents' decision-making. 
At each time step, which can be interpreted as a year, every farmer makes decisions regarding conservation practice adoption. Farmers can choose to adopt none or a combination of the practices. The practices available to farmers tackle the non-point source pollution by controlling the pollution source (nutrient management), trapping the soil particles before they reach water bodies (structural practices, i.e, filter strips), promoting long-term conservation covers (land retirement, CRP), and reducing soil disturbance (non-structural practices, i.e., conservation tillage and no-till systems) (Table 1-3).

Farmers' adoption decisions have temporal consequences. That is, if a farmer enrolls in land retirement programs and signs a CRP contract, the commitment is a multi-year commitment, where in case of contract breach a penalty has to be paid. Similarly, adoption of structural practices such as filter strips requires a multi-year commitment as well because farmers receive economic incentives from the government. Adoption decisions of non-structural practices and nutrient management plans, however, are made on a yearly basis, and do not entail a penalty. In this model, we assume every farmer to be eligible for land retirement enrollment and every farmer who adopts structural practices to be eligible for $50 \%$ cost share incentive provided by the government.

Adoption of structural and non-structural practices, land retirement enrollment, and participation in nutrient management plans are voluntary decisions. Each farmer determines whether to enroll in land retirement programs (such as CRP), to adopt certain conservation practices, or choose not to adopt any practice, depending on their farm's overall objective. The overall objective is a combination of multiple objectives that include the profitability of the business, attitudes towards different conservation practices depending on farmer type, and influences of the spatial and social network. These objectives, each represented by a specific function, are combined in a single function that represents the overall utility of the farmer (Equation 1.1).

Every period, the overall utility to a farmer for every conservation practice adoption option (e.g., no conservation practice at all, single conservation practice adoption or a combination of conservation practices) is calculated. The list of conservation practices and their combinations are given in Table 1-3.

\begin{tabular}{ll}
\hline$i$ & Conservation practice \\
\hline 0 & None \\
1 & Non-structural practices (no-till) \\
2 & Structural practices (filter strips) \\
3 & Land retirement programs (CRP) \\
4 & Nutrient management plans \\
5 & Non-structural practices (no-till) \& Structural practices (filter strips) \\
6 & Non-structural practices (no-till) \& Nutrient management plans \\
7 & Structural practices (filter strips) \& Nutrient management plans \\
8 & Non-structural practices (no-till) \& Structural practices (filter strips) \\
& \& Nutrient management plans \\
\hline
\end{tabular}


The decision algorithm combines all of the available information to the farmer and integrates for the adoption decision. This mechanism includes the profit generated from agricultural production, availability of government programs and policies, influence of the farmers' neighbors and farmers' intrinsic attributes. These are all combined within a utility function, $\mathrm{F}_{\text {decide }}(i, j)$ for the conservation practice combination $i$ and farmer $j$, which is a combination of 4 sub-functions (Equation 1.1).

Once the farmer calculates utility of each conservation practice, the values of utility are transformed into choice probability using logit model. Logit framework allows us to incorporate both uncertainty in decision-making and the bounded rationality of the farmers as it assigns probabilities to different options, where the probability of an inferior option could be non-zero (Equation 1.2).

$$
\begin{aligned}
& \mathrm{F}_{\text {decide }}(i, j)=\mathrm{b}_{1} \mathrm{~F}_{\text {econ }}(i, j)+\mathrm{b}_{2} \mathrm{~F}_{\text {profile }}(i, j)+\mathrm{b}_{3} \mathrm{~F}_{\text {social }}(i, j)+\mathrm{b}_{4} \mathrm{~F}_{\text {spatial }}(i, j) \\
& \text { Selection_probability }(i, j)=\mathrm{e}^{\text {Fdecide }(i, j)} / \Sigma \mathrm{e}^{\text {Fdecide }(i, j)}
\end{aligned}
$$

In every period, for every farmer $(j), \mathrm{F}_{\text {decide }}(i, j)$ is calculated for all possible combinations of the conservation practices $(i)$. In this function $\mathrm{F}_{\text {econ }}(i, j)$ represents the agricultural profit generated with production, $\mathrm{F}_{\text {profile }}(i, j)$, the intrinsic attributes of the farmer towards the given conservation practice combination, which is determined by its type, $\mathrm{F}_{\text {social }}(i, j)$, the influence of the farmer's social network and $\mathrm{F}_{\text {spatial }}(i, j)$, the influence of the spatial network, i.e. the farmer's neighbors. $\mathrm{F}_{\text {social }}(i, j)$ and $\mathrm{F}_{\text {spatial }}(i, j)$ are also influenced by the farmer typology. The weights (b) for each component are informed by the farmer typology and determined using a matrix method (Appendix C). One of the important modeling choices that incorporate the differences between the different farmer types is the assignment of the weights (b). These weights are assigned in such a way that the farmer types whose income source is solely farming, and the types with profit maximizing mindset (i.e., business-oriented farmers) put more emphasis to $\mathrm{F}_{\text {econ }}(i, j)$, while farmers with more connection to the landscape (i.e., traditional farmers) put more emphasis on $\mathrm{F}_{\text {profile }}(i, j)$. Because non-operators do not live in the county in which they own land, or they do not have a farming background, they are not connected to the information networks have no $b$ values for $\mathrm{F}_{\text {spatial }}$ and $\mathrm{F}_{\text {social. }}$. More details on each component of the $\mathrm{F}_{\text {decide }}(i, j)$ function is given in subsequent sections.

\section{Agricultural Profit Dynamics, $F_{\text {econ }}(i, j)$}

Farmers generate revenue by enrolling in land retirement programs and allocating land to the CRP or by crop production. If the farmer enrolls in land retirement programs, a fixed payment depending on the farm size and CRP rental rate is paid at the beginning of each year the farmer allocates land for retirement programs. There will be no further agricultural revenue generated from production for the farmer in that case, and that payment will be equal to $F_{\text {econ }}(i)$. Otherwise, the farmer's expected earning is calculated using the farm size, the price and yield of the crop that the farmer expects to get, governmental support for enrolling agricultural programs, and costs associated with production and conservation practice adoption. Single period profit function of a farmer producing a single crop is written below in two forms representing policy scenarios of with crop revenue insurance and without crop revenue insurance. In our models, the commodity payments such as direct payments are not represented explicitly. 


$$
\mathrm{F}_{\text {econ }}(i, j)=\mathrm{p}(\mathrm{A}-\mathrm{F}) \mathrm{Y}(\mathrm{z})+\mathrm{gF}+\mathrm{rA}-\mathrm{c}
$$

without crop revenue insurance program

$$
\mathrm{F}_{\text {econ }}(i, j)=\mathrm{p}(\mathrm{A}-\mathrm{F}) \mathrm{Y}(1, \mathrm{z})+\mathrm{gF}+\mathrm{rA}-\mathrm{c}-\mathrm{p}(\mathrm{l})
$$

where $\mathrm{F}_{\text {econ }}(i, j)$ is profit, $\mathrm{p}$ is farmer's expected crop price (corn, soybean or winter wheat), A is the production area (acres), $\mathrm{Y}$ is the farm's expected effective yield per acre, $\mathrm{g}$ denotes per acre economic incentive associated with structural practice adoption, $\mathrm{F}$ is total land allocated for structural practices, $r$ is the CRP per acre payment to the farmer, $\mathrm{z}$ is a measure of fertilizer input on the farm, $\mathrm{c}$ is the total cost of production including cost of conservation practice adoption, $\mathrm{p}$ is the per acre premium rate for crop revenue insurance, and 1 is the level of insurance purchased. In this model we assume $75 \%$ coverage level for revenue insurance.

Agricultural crop production generates revenue (market price multiplied by production size and expected yield). Agricultural profit dynamics also include government payments (such as payments to incentivize structural practice adoption), insurance indemnities if enrolled in crop revenue insurance program, and cost production including maintenance, input, and labor costs as well. To represent the agricultural production cost, a current farm budgeting model developed by Ohio and Iowa State Universities is adopted and adjusted to previous years using historic consumer price index.

Practices that farmers adopt influence the size of the production area and expected yield; therefore they affect the expected agricultural profit. For example, when a farmer implements structural practices, the size of the filter strip is subtracted from the total size of the farm. Moreover, with nutrient management plans the expected yield decreases. Therefore, $F_{\text {econ }}$ value for each conservation practice available in Table 1-3 is calculated separately.

Expected Price and Yield: Expected prices and yield values heavily influence the resulting farm profit. These parameters are based on previous year's price and yield values and updated by each farmer influenced by their farmer type.

In the model, for actual crop yields and prices historical values are used (available at http://usda.mannlib.cornell.edu and http://www.farmdoc.illinois.edu). In any given time, based on the actual previous crop yields and prices, farmers use Bayesian inference to form price and yield expectations. While a farmer's yield expectation is in the form of a point prediction, a probability distribution is formed for crop prices by taking the price expectation as the mean. Bayesian inference is a statistical approach used to update farmer's existing expectations against observed values of crop price and yield. The Bayesian inference allows farmers to be connected to agricultural markets and at the same time 'learn' with experience. Moreover, with Bayesian inference, we can represent the heterogeneity of farmers by setting different parameters for updating their priors for crop prices and yields depending on the farmer type. For example, traditional farmers are more anchored so that realization of outliers do not affect their expectations much while business-oriented farmers are better at following the fluctuations in the market. 
Bayesian inference algorithm is run every year, hence farmers' perceptions for crop prices 250 and yields change annually. At the beginning of each year, farmers use publicly available price 251 and yield information from the previous year, their experiences and personalities to form future 252 price and yield expectations.

2. Intrinsic typology attributes, $F_{\text {profile }}(i, j)$

Farmer typology developed informs $F_{\text {profile }}$ values for each farmer type and conservation practice (Daloğlu et al. 2014). F profile $(i, j)$ lets farmers to adopt economically infeasible practices because of their attitudes and preferences such as being a good citizen of the environment (Table 1-4). The synthesis of the adoption literature supports the $F$ profile values, which change for every practice and every farmer type. In other words, $\mathrm{F}_{\text {profile }}$ is the variable representing the socio-

261 tenure arrangements in adoption decisions (Table 1-5). 


\begin{tabular}{|c|c|}
\hline Farmer Type & Land Management Attitudes \\
\hline \multirow{3}{*}{ Traditional } & $\begin{array}{l}\text { - favor non-structural practices because of potential } \\
\text { reduction in labor requirements } \rightarrow \text { high } \mathrm{F} \text { profile } \\
\text { values }\end{array}$ \\
\hline & $\begin{array}{l}\text { - financial investment requirement leads to lower } \\
\text { adoption rates for structural practices } \rightarrow \text { low } \mathrm{F} \text { profile } \\
\text { values }\end{array}$ \\
\hline & $\begin{array}{l}\text { - secure income provided by land retirement } \\
\text { programs is appealing } \rightarrow \text { high } F \text { profile values }\end{array}$ \\
\hline \multirow{3}{*}{ Supplementary } & $\begin{array}{l}\text { - favor non-structural practices because of potential } \\
\text { reduction in labor requirements } \rightarrow \text { high } \mathrm{F}_{\text {profile }} \\
\text { values }\end{array}$ \\
\hline & $\begin{array}{l}\text { - substantial off-farm income leads to higher } \\
\text { adoption rates for structural practices } \rightarrow \text { high F } \\
\text { profile values }\end{array}$ \\
\hline & $\begin{array}{l}\text { - secure income provided by land retirement } \\
\text { programs is appealing } \rightarrow \text { high } \mathrm{F}_{\text {profile values }}\end{array}$ \\
\hline \multirow{3}{*}{ Business-oriented } & $\begin{array}{l}\text { - favor non-structural practices because of potential } \\
\text { reduction in labor requirements } \rightarrow \text { high } \mathrm{F}_{\text {profile }} \\
\text { values }\end{array}$ \\
\hline & $\begin{array}{l}\text { - long-term plans and dependence on soil quality } \\
\text { leads to higher structural practice adoption } \rightarrow \text { high } \\
F_{\text {profile values }}\end{array}$ \\
\hline & $\begin{array}{l}\text { - focused on profitability, leading to low } \\
\text { enrollment rates in land retirement programs } \rightarrow \\
\text { low } F_{\text {profile }} \text { values }\end{array}$ \\
\hline \multirow{3}{*}{$\begin{array}{l}\text { Non-operator owner } \\
\text { Absentee landowners: own the } \\
\text { land but do not reside on or } \\
\text { operate it (Petrzelka et al., } \\
\text { 2011) } \\
\text { Investors: describe themselves } \\
\text { as never having farmed } \\
\text { (Nassauer et al., 2011). } \\
\text { Mutually exclusive subtypes. }\end{array}$} & $\begin{array}{l}\text { - favor non-structural and structural practices } \\
\text { because of potential contribution to increased water } \\
\text { quality } \rightarrow \text { high } F \text { profile values }\end{array}$ \\
\hline & $\begin{array}{l}\text { - absentee landowners favor land retirement } \\
\text { programs } \rightarrow \text { high } \mathrm{F}_{\text {profile }} \text { values }\end{array}$ \\
\hline & $\begin{array}{l}\text { - investors have lower enrollment rates for land } \\
\text { retirement programs } \rightarrow \text { low } \mathrm{F}_{\text {profile values }}\end{array}$ \\
\hline
\end{tabular}

Table 1-4: Farmer typology and its influence on $F$ profile values (adapted from Daloğlu et al. 2014) 
The $\mathrm{F}$ profile value for each farmer type and conservation practice is determined using prioritization matrix method and the synthesis of the adoption literature (Table 1-4, Daloğlu et al. 2014). The prioritization matrix, also known as criteria matrix, provides a way of sorting a diverse set of items into an order of importance. It also enables their relative importance to be identified deriving a numerical value of the importance of each variable.

\begin{tabular}{cccccc} 
& \multicolumn{5}{c}{$\mathrm{F}_{\text {profile }}$} \\
\cline { 2 - 6 } & Traditional & Supplementary & $\begin{array}{l}\text { Business- } \\
\text { oriented }\end{array}$ & Anvestor & $\begin{array}{c}\text { Absentee } \\
\text { Landowner }\end{array}$ \\
\hline 0 & 0.90 & 0.36 & 0.28 & 0.00 & 0.00 \\
\hline 1 & 0.68 & 0.49 & 0.74 & 1.00 & 1.00 \\
\hline 2 & 0.00 & 0.06 & 0.20 & 0.37 & 0.60 \\
\hline 3 & 1.00 & 1.00 & 0.00 & 0.48 & 0.17 \\
\hline 4 & 0.43 & 0.17 & 0.43 & 0.13 & 0.12 \\
\hline 5 & 0.10 & 0.22 & 0.36 & 0.55 & 0.72 \\
\hline 6 & 0.51 & 0.17 & 1.00 & 0.30 & 0.31 \\
\hline 7 & 0.08 & 0.17 & 0.28 & 0.55 & 0.62 \\
\hline 8 & 0.07 & 0 & 0.31 & 0.86 & 0.63
\end{tabular}

To represent interactions between agents, there are several artificial social network structures such as lattice, small-world, scale-free and random networks. As little to no data is available for the historical and current social network structure of the farmers we chose to rely on artificial network structures. After a comparison of widely used social network structures, Hamill and Gilbert (2009) suggest a simple but at the same time sociologically realistic network structure. To represent the varying network connectedness of agents displayed in the farmer typology, this social network is suitable.

Hamill and Gilbert (2009) base their network structure on the analogy of social circles. In the social network, agents are permitted to have links with other agents who can reciprocate. The agent population is divided into two circles with small and large social reaches. This network structure allows representing individuals who are more connected than rest of the population by placing them in the social circle that has larger social reach. When the social reach is larger, the size of the personal network would be larger as well. In our model, business-oriented agents are located in a social circle that has larger social reach than supplementary and traditional farmer agents which results in increased number of connections for business-oriented farmers. This network structure also allows us to connect business-oriented farmers more to other businessoriented farmers. Non-operator owners (investors and absentee landowners) are initially not connected to the social network. However, to demonstrate the potential impacts of information networks on non-operator owner decision, we simulate a scenario that assumes absentee landowners connect to the social network whereas investors connect to both spatial and social networks as they live close to the farmland that they own. Through the information networks (spatial and social networks), farmers observe their neighbors' adoption decisions. 
Both $\mathrm{F}_{\text {spatial }}(i, j)$ and $\mathrm{F}_{\text {social }}(i, j)$ are calculated for every farmer for every possible conservation practice given in Table 1-2. $\mathrm{F}_{\text {spatial }}$ represents the percentage of Moore neighbors (the eight cells surrounding a central cell on a two-dimensional square lattice) adopting a certain conservation practice. Moore neighbors of a farmer comprise the immediate eight spatial neighbors that every farmer has, except the farmers on the edge if two-dimension grid space.

$$
\mathrm{F}_{\text {spatial }}(i, j)=\operatorname{Neighbors}(i, j) / \quad \boldsymbol{\Sigma} \text { Neighbors }(i, j)
$$

where Neighbors $(\mathrm{i}, \mathrm{j})$ is the number of Moore neighbors that adopted the conservation practice combination $\mathrm{j}$. That is, $\mathrm{F}_{\text {spatial }}(i)$ is a measure of popularity of conservation practice combination $i$ in the immediate neighborhood of the given farmer. Higher the popularity of a conservation practice in spatial sense, higher the probability of the farmer adopting that conservation practice.

$\mathrm{F}_{\text {social }}$ represents the percentage of neighbors adopting a certain conservation practice. Similarly, $\mathrm{F}_{\text {social }}$ is calculated for every possible conservation practice listed in Table 1-3. Connectedness in the social network is not uniform among the farmers. The number of connections of a farmer depends on its type. Moreover, among the farmers of a given type, the number of connections may differ, representing the heterogeneity of the farmers within the same type. However, the variation in the number of connections among the farmers of the same type is smaller than the variation between farmers of different types. For example, business-oriented farmers have higher number of social connections than the other farmers on average, while the connections of the business-oriented farmers are mostly to other business-oriented farmers. Traditional and supplementary farmers have lower number of connections. In a similar manner as $\mathrm{F}_{\text {spatial }}(i, j), \mathrm{F}_{\text {social }}(i, j)$ measures the popularity of the conservation practice combination $\mathrm{i}$ among the parts of the social network that are connected to the given farmer. $\mathrm{F}_{\text {social }}(i, j)$ can be written as follows:

$$
\mathrm{F}_{\text {social }}(i, j)=\quad \operatorname{Network}(i, j) / \boldsymbol{\Sigma} \operatorname{Network}(i, j)
$$

where $\operatorname{Network}(i, j)$ is the number of farmers that selected the conservation practice adoption $i$ within the farmer $j$ 's social network.

Non-operator owners (investors and absentee landowners) are not initially connected to spatial and social networks. Therefore, initially they have no influence of information networks on their conservation adoption decisions. When increased involvement of non-operator owners in decision-making is simulated, absentee-landowners are only connected to the social network and investors are connected to both spatial and social networks. For non-operator owners, social networks are assumed to be NGOs and government agencies leading to a positive influence. 


\section{Policy Scenarios}

We simulated four scenarios intended to form a bridge between the science of land management and policy development (Table 1-6). The primary goal of these plausible policy scenarios is to be prospective and informative rather than projective or prescriptive of the future (Nassauer and Corry, 2004).

\begin{tabular}{|c|c|c|c|}
\hline & \multicolumn{2}{|c|}{ NON-OPERATOR INVOLVEMENT } \\
\hline \multirow{2}{*}{} & NO & NO & YES \\
\cline { 2 - 4 } & & $\begin{array}{c}\text { 1 Baseline } \\
\text { of existing land tenure and } \\
\text { policy context }\end{array}$ & $\begin{array}{c}\text { 2 Non-operator owners involvement } \\
\text { Increased non-operator involvement in } \\
\text { land management decisions }\end{array}$ \\
\cline { 2 - 4 } & YES & $\begin{array}{c}\text { 3 Crop revenue insurance } \\
\text { Only operators are decision } \\
\text { makers and crop revenue } \\
\text { insurance is available as a } \\
\text { risk management tool }\end{array}$ & $\begin{array}{c}\text { 4 Crop revenue insurance with non- } \\
\text { operator owner involvement } \\
\text { Botherators and non-operators owners } \\
\text { are decision makers and crop revenue } \\
\text { insurance is available as a risk } \\
\text { management tool }\end{array}$ \\
\hline
\end{tabular}

Table 1-6: Land management strategies tested under different agricultural policy and structure scenarios

The Baseline scenario (1) represents a simplified version of existing land tenure where operators (traditional, supplementary and business-oriented farmers) are responsible for conservation practice adoption decisions and non-operator owners have no involvement in production and conservation decisions. In this scenario existing crop insurance programs are not represented and crop revenue insurance is not offered in lieu of commodity payments.

The Non-operator owner involvement scenario (2) simulates the potential impact of non-operator owners being more involved in decisions about conservation practice adoption. This premise follows recent research that demonstrated positive attitudes of non-operator owners for certain conservation practices (Petrzelka et al., 2009; Nassauer et al., 2011). In this scenario, we assume natural resource agencies and NGOs reach out to non-operator owners and effectively inform them about existing and available conservation practices.

The Crop revenue insurance scenario (3) follows the latest US Farm Bill discussions about providing federally subsidized crop revenue insurance rather than commodity production subsidies. This scenario does not assume that conservation compliance is required for land to be eligible for crop revenue insurance. In this scenario, only operators are decision makers and they purchase crop revenue insurance at $75 \%$ coverage level for all the land that they manage including the rented land. Crop revenue insurance provides an accessible risk management tool to operators and at the same time encourages an increased production area.

The Crop revenue insurance with non-operator owner involvement scenario (4) presents the plausible changes both in land tenure and policy by assuming non-operators owners as active decision makers when crop revenue insurance is offered in lieu of commodity payments. Crop 
revenue insurance provides a safety net and indirectly motivates both operators and non-operator owners to increase their production area.

Certain model parameters are changed depending on the policy scenario being investigated. Appendix 3 has initial model parameter values and how we change these values for different scenarios.

\section{Verification and Validation}

$\mathrm{ABMs}$ are informative rather than predictive and useful in investigating plausible scenarios and their potential consequences. Model verification and validation are important steps that contribute to the validity of the developed ABM. Model verification is the process of determining whether the software implementation correctly represent model processes (Ormerod and Rosewell, 2009). As the ABMs are powerful in illustrating the phenomena of emergence, it 381 is particularly difficult to determine whether an unexpected result is due to an error in the model 382 implementation and execution (Galan et al., 2009). Therefore the verification stage of the model 383 is particularly important. For the verification of the model, where the general aim is to make sure 384 that the model does not have programming errors, we built the model in several levels with 385 increasing complexity following unit testing approach (Linck and Frohlick, 2003) (Figure 1-4). 386 The unit testing approach suggests writing some test code to exercise the program 387 simultaneously writing the complete model code. The purpose is to construct the model in small, 388 self-contained units and check the results and make sure they align with expected results. 


\begin{tabular}{|l|}
\hline \multicolumn{1}{|c|}{$\begin{array}{c}\text { Level1 } \\
\text { Isolated World }\end{array}$} \\
\hline - Developer creates owners, operators, and farmland \\
\hline $\begin{array}{l}1 \text { a) Farmers give adoption decisions using only profit } \\
\text { generated from agricultural production (F econ). } \\
1 \text { b) Farmers add the infleunce of policy relevant } \\
\text { characteristics to their decisons (F profile). }\end{array}$ \\
\hline
\end{tabular}

\begin{tabular}{|l|}
\multicolumn{1}{|c|}{ Level 2} \\
Information Networks \\
\hline - Developer creates owners, operators, and farmland \\
- Spatial and social networks \\
\hline - Farmers give adoption decisions with the influence of \\
profit generated from agricultural production (F econ) \\
and policy-relevant farmer characteristics (F profile) \\
2 a) Influence of spatial networks is added (F spatial) \\
2 b) Influence of social networks is added (F social) \\
\end{tabular}

\begin{tabular}{|l|}
\hline \multicolumn{1}{|c|}{ Level 3} \\
Information Networks + Policy and Land Tenue Changes \\
\hline - Developer creates owners, operators, and farmland \\
- Spatial and social networks \\
- Agricultural policy and land tenure dynamics change \\
to represent plausible future scenarios \\
\hline - Farmers give adoption decisions with the influence of \\
profit generated from agricultural production (F econ), \\
policy-relevant farmer characteristics ( $F$ profile), and \\
infromation networks (F spatial and F social) \\
3 a) Non-operators are involved in the decision making \\
process and are connected to information networks \\
3 b) Crop revenue insurance is offered as a risk \\
management tool.
\end{tabular}

Figure 1-4: Levels of $\mathrm{ABM}$ as a verification tool

391 Model validation is the process of assessing the degree of which the model is accurately 392 representing the real world interactions and dynamics (Ormerod and Rosewell, 2009). For the 393 farmer typology, we synthesized the literature of conservation practice adoption (Daloğlu et al., 394 2014). Therefore, for model validation we used the documented trends in the Corn Belt. 395 Synthesis of numerous studies conducted in the Corn Belt provides spatially and temporally 
generalizable trends to compare and validate model results. Comparison of documented adoption rates for non-structural practices (CTIC, 2012) and enrollment rates for land retirement programs such as CRP (USDA, 2013) are within the simulated adoption rates (Figures 1-5 and 1-6). For structural practices, we refer to empirical studies conducted in Ohio, which indicate $20-25 \%$

400 adoption rates similar to ABM results (Napier et al., 2000; Napier and Bridges, 2003).

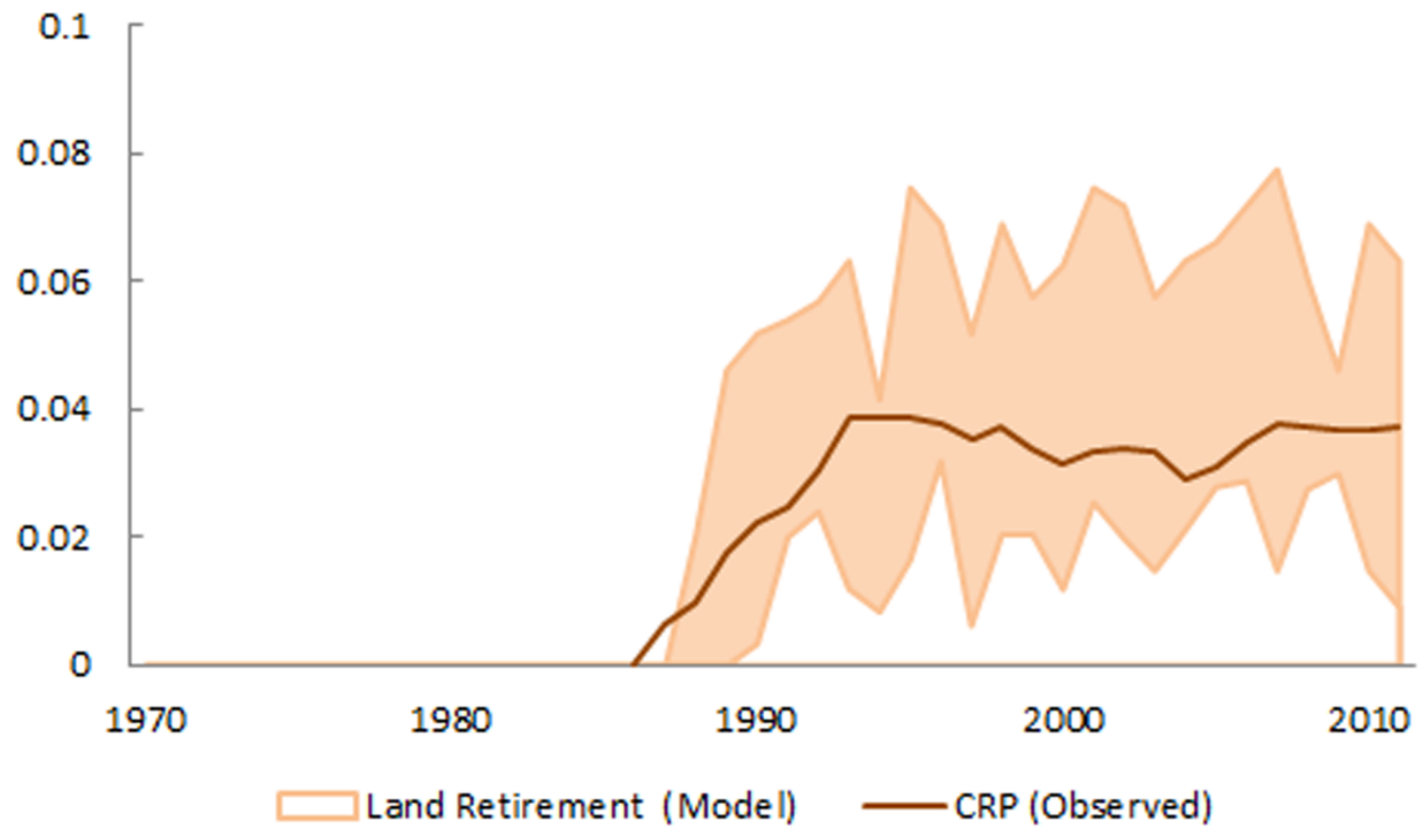




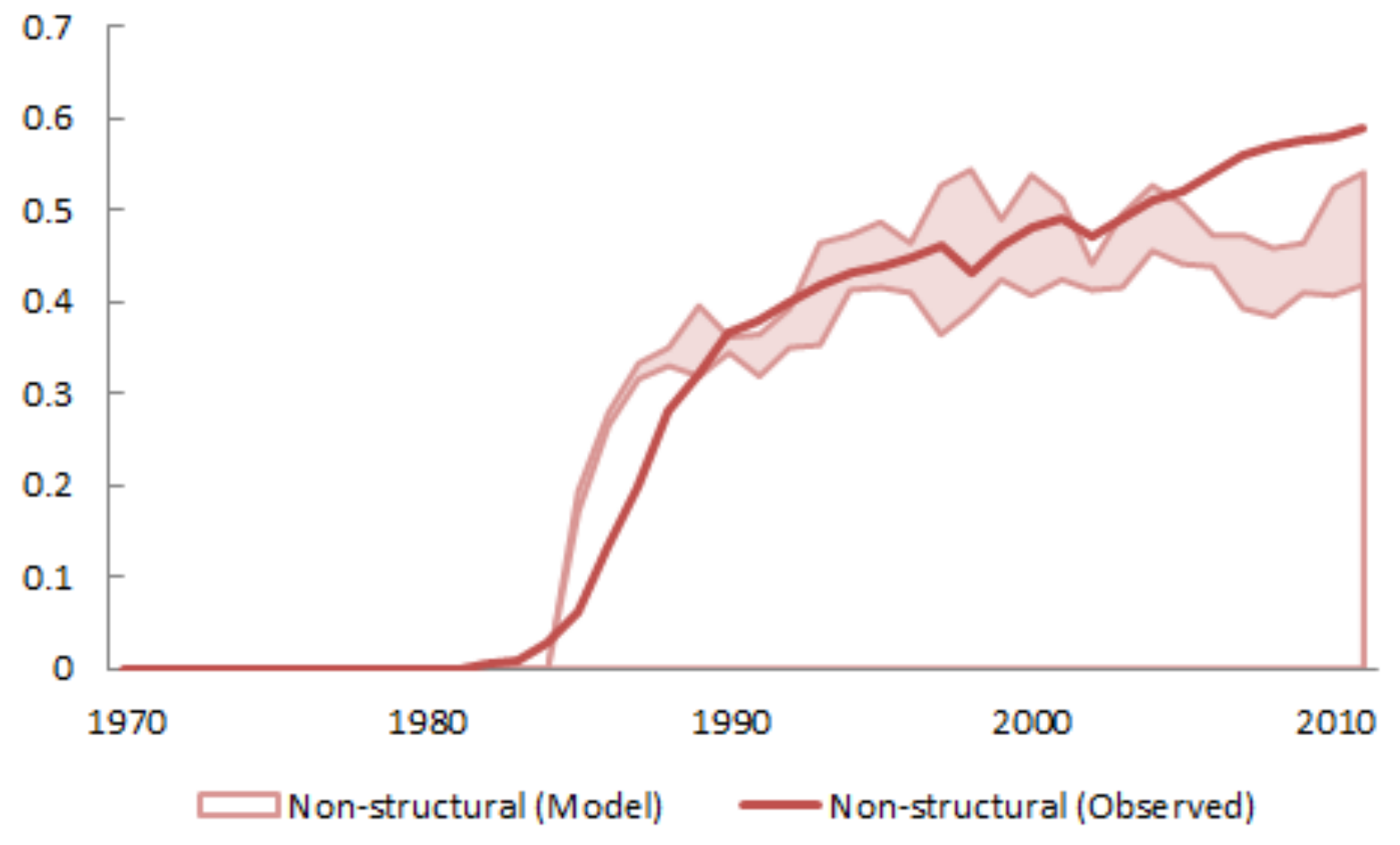

Figure 1-6: Observed and simulated adoption rates for non-structural practices such as 408 conservation tillage and no-till in Sandusky watershed, OH (CTIC, 2012). 25 ABM simulation runs fall between two lines of the same color. 


\section{Literature Cited}

410 Brown, D.G., Riolo, R., Robinson, D.T., North, M., and Rand, W. 2005. Spatial process and data models: Toward integration of agent-based models and GIS. Journal of Geographical Systems. 7 (1): 25-47.

CTIC. 2012.The National Crop ResidueManagement Survey by Conservation Technology Information Center (CTIC). Purdue University.

Daloğlu, I., Nassauer, J.I., Riolo., R.L., Scavia, D. 2014. Development of a farmer typology of agricultural conservation behavior in the American Corn Belt. Agricultural Systems. DOI: $10.1016 /$ j.agsy.2014.05.007

Galan, J. M., Izquierdo, L. R., Izquierdo, S. S., Santos, J. I., del, O. R., Lopez-Paredes, A., \& Edmonds, B. 2009. Errors and artefacts in agent-based modelling. Journal of Artificial Societies and Social Simulations, 12, 1.

Grimm, V., Berger, U., Bastiansen, F., Eliassen, S., Ginot, V., Giske, J., Goss-Custard, J., Grand, T., Heinz, S.K., Huse, G., Huth, A., Jepse, J.U., Jorgensen, C., Mooiji, W., Muller, B., Pe'er, G., Piou, C., Railsback, S.E., Robbins, A.M., Robbins, M.M., Rossmanith, E., Ruger, N., Strand, E., Souissi, S., Stillman, R.A., Vabo, R., Visser, U., DeAngelis, D. L. 2006. A standard protocol for describing individual-based and agent-based models. Ecological Modelling, 198, 115-126.

Grimm, V., Berger, U., DeAngelis, D. L., Polhill, J. G., Giske, J., \& Railsback, S. F. 2010. The ODD protocol: A review and first update. Ecological Modelling, 221, 23, 2760-2768.

Hamill, L., \& Gilbert, N. 2009. Social circles: A simple structure for agent-based social network models. Journal of Artificial Societies and Social Simulation, 12, 2.

Link, J., \& Frohlich, P.2003. Unit testing in java: How tests drive the code. San Francisco: Morgan Kaufmann.

Napier, T.L., Bridges, T., 2002. Adoption of conservation production systems in two Ohio watersheds: A comparative study. J Soil Water Conserv 57, 229-235.

Napier, T. L., M. Tucker, and S. McCarter. 2000. Adoption of conservation production systems in three Midwest watersheds. Journal of Soil and Water Conservation 55 (2):123-134.

Nassauer, J. I., \& Corry, R. C. 2004. Using normative scenarios in landscape ecology. Landscape Ecology, 19(4), 343-356.

Ormerod, P., \& Rosewell, B. 2009. Validation and Verification of Agent-Based Models in the Social Sciences. Lecture Notes in Computer Science, 5466, 130-140.

USDA. 2013. Conservation Programs, Statistics. Retrieved March 19, 2013, from http://www.fsa.usda.gov/FSA/ 


\section{Appendix 2: Linking ABM with SWAT}

Once all farmer adoption status is updated, the ABM output in the abstract grid file provides the adoption status for every farmer in every period and is used to make the necessary updates in relevant input files of SWAT in the Sandusky watershed file. Abstract grid cell characteristics are assigned to Sandusky watershed locations by the smallest computational unit of SWAT, HRUs. SWAT is then run for the whole simulation period (1970-2010) to provide water quality metrics such as sediment and phosphorus loads. The input files for SWAT are all in ASCII text format, making it easy to interface with the ABM and this linkage is supported with the MatLab programming language.

For each year, farmers' decisions regarding conservation practice adoption are used to modify several SWAT input files. For example, if a farmer adopts non-structural practices such as no-till instead of conventional tillage, the land management input file (.mgt) in SWAT is modified to reflect this change. Similarly, if a farmer adopts structural practices such as filter strips, the operations input file (.ops) is updated with a filter strip of $10 \mathrm{~m}$ width. Because farmers receive economic incentives to adopt structural practices, their continued use of filter strips is expected. For enrollment in land retirement programs, we change the land cover type in the input file (.mgt) to be one of the perennial covers such as big bluestem without fertilizer application. Once a farmer enrolls in land retirement programs, adherence to the contract is mandatory for at least 10 years as a requirement of the program. If a farmer adopts nutrient management plan, then a $20 \%$ reduction in fertilizer application rate is assumed. This change is also reflected in the management input file of SWAT (.mgt).

The decision algorithm used by our farmers includes social and spatial networks, which influence their adoption decisions. Throughout the simulation period, farmers are programmed to observe their neighbors and the conservation practices they adopt. Therefore, in our model, the process of conservation practice adoption has the necessary spatial component and shows variance in each simulation. For the purposes of illustration, we reported the average load reductions from numerous simulations but also included the variability in error bars (Figures 5-6, main text). Due to the stochasticity built-in the model, in each ABM initialization, different farmer types are assigned to each farmer, which results in different decision-making characteristics. Each ABM run result has different spatial locations for conservation practices. The initial spatial distribution of farmer types affects the social and spatial network structure and has thus an impact on the final spatial distribution of adopted practices. For example, if a farmer located in the downstream part of the watershed adopts a conservation practice, its impact on water quality would be different than adopting a practice in the upstream part of the watershed. To eliminate this initial condition bias, we perform numerous ABM runs and link those to SWAT, which yields differences in water quality metrics as well; hence the bars demonstrate this impact of the different implementation locations of the conservation practices. 


\section{Challenges of Linking Agent-based Models with Biophysical Models}

This framework is designed to investigate the impact of alternative policy approaches and changing land tenure dynamics on farmer adoption of conservation practices intended to increase the water quality. For this purpose, we chose to link SWAT with ABM for farmer adoption of conservation practices. Because SWAT is a river basin scale water quality model developed to assess the water quality benefits of conservation practices (Gassman et al. 2007; Osmond 2010), linking it with $\mathrm{ABM}$ aligns with the purpose of our framework.

For this framework, we chose a loose integration method, which uses the state variables from one model as a driving variable in the other model (Antle et al., 2001). ABM determines the land management pattern for the Sandusky watershed and SWAT estimates water quality metrics as a function of the updated land management pattern. One of the disadvantages of using loosely coupled models is the computational overhead associated extracting output files and modifying input files. We used MatLab programming language to link ABM output and modify necessary SWAT input files. Single SWAT run including the modification of input files for 41 years (1970-2010) averaged about 55 minutes when run on quad-core Windows machine. Because of the stochasticity built in the model, we performed 25 simulations and reported the averages of these runs for water quality metrics, which resulted in approximately 1,375 minutes or 0.95 days.

In this framework, we aimed to represent the farm-scale decision-making regarding conservation practice adoption. However, due to limited data, representation of the exact location of farms and long-term management decisions is not possible. Therefore, we constructed an abstract ABM without the spatial representation of decision-making process which could affect the farmers' conservation decisions because soil properties and slope of their land are not influential in their adoption decisions.

The capabilities of SWAT were the determining factor for the scale of the linked model. We developed a fine-scale SWAT model to match the average farm size in the Sandusky basin (Daloğlu et al., 2012). However, SWAT is not developed on grid cells and the smallest computational unit of SWAT, HRU cannot be manually delineated which complicates the representation of farm level decision making.

Linking social and biophysical models for social-ecological system representation is profoundly valuable, especially in evaluating plausible policy scenarios. While the recent land use and land change research has contributed to this endeavor, this study goes one step further by linking a widely used water quality model to $\mathrm{ABM}$ to better represent the dynamic interactions of farmers. 


\section{Literature Cited}

Antle, J. M., \& Stoorvogel, J. 2001. Integrating site-specific biophysical and economic models to assess trade-offs in sustainable land use and soil quality. Economic Policy and Sustainable Land Use : Recent Advances in Quantitative Analysis for Developing Countries / Nico Heerink, Herman Van Keulen, Marijke Kuiper, Editors.

83 Daloğlu, I., K.H. Cho, D. Scavia. 2012. Evaluating causes of trends in long-term dissolved reactive phosphorus loads to Lake Erie. Environ. Sci. Technol. 46:10660-10666 http://dx.doi.org/10.1021/es302315d.

Gassman, P.W., Reyes, M.R., Green, C.H., Arnold, J.G., 2007. The soil and water assessment tool: Historical development, applications, and future research directions. T Asabe 50, 1211-1250.

Osmond, D. L. 2010. USDA water quality projects and the National Institute of Food and Agriculture Conservation Effects Assessment Project watershed studies. Journal of Soil and Water Conservation 65 (6):142a-146a. 
Appendix 3: Model parameters for the agent-based model of farmer adoption of conservation practices

\begin{tabular}{|c|c|c|}
\hline Name & Parameter description & Value \\
\hline percentBus & percentage of business-oriented farmers & 0.1 \\
\hline percentSuppl & percentage of supplementary farmers & 0.2 \\
\hline percentTrad & percentage of traditional farmers & 0.7 \\
\hline initialAdopted0 & $\begin{array}{l}\text { percentage of farmers that adopted none of } \\
\text { the practices }\end{array}$ & 0.8 \\
\hline initialAdoptedl & $\begin{array}{l}\text { percentage of farmers that adopted non- } \\
\text { structural practices }\end{array}$ & 0.0 \\
\hline initialAdopted2 & $\begin{array}{l}\text { percentage of farmers that adopted structural } \\
\text { practices }\end{array}$ & 0.1 \\
\hline initialAdopted 3 & $\begin{array}{l}\text { percentage of farmers that enrolled in land } \\
\text { retirement programs }\end{array}$ & 0.0 \\
\hline initialAdopted4 & $\begin{array}{l}\text { percentage of farmers that adopted nutrient } \\
\text { management plan }\end{array}$ & 0.1 \\
\hline initialAdopted 5 & $\begin{array}{l}\text { percentage of farmers that adopted non- } \\
\text { structural and structural practices }\end{array}$ & 0.0 \\
\hline initialAdopted6 & $\begin{array}{l}\text { percentage of farmers that adopted non- } \\
\text { structural practices and nutrient management } \\
\text { plan }\end{array}$ & 0.0 \\
\hline initialAdopted 7 & $\begin{array}{l}\text { percentage of farmers that adopted structural } \\
\text { practices and nutrient management plan }\end{array}$ & 0.0 \\
\hline ownerInterference & $\begin{array}{l}\text { percentage of non-operator owners initially } \\
\text { giving decisions }\end{array}$ & 0.0 \\
\hline ownerMaxInterference & $\begin{array}{l}\text { percentage of non-operator owners giving } \\
\text { decisions at the end of the simulation }\end{array}$ & 0.8 \\
\hline farmerAgeToLeave & $\begin{array}{l}\text { age at which traditional farmers consider } \\
\text { leaving business }\end{array}$ & 65 \\
\hline farmerProbToLeave & $\begin{array}{l}\text { probability that traditional farmers leave } \\
\text { business }\end{array}$ & 0.8 \\
\hline farmerProbNonoperator & $\begin{array}{l}\text { probability that traditional farmers leaving the } \\
\text { business become non-operator owners }\end{array}$ & 0.6 \\
\hline farmerProbAbsentee & $\begin{array}{l}\text { probability that traditional farmers leaving the } \\
\text { business become absentee landowners. }\end{array}$ & 0.6 \\
\hline ciLevel & level of crop revenue insurance coverage & 0.8 \\
\hline
\end{tabular}




\begin{tabular}{|c|l|c|} 
simpleCiPlusMinusBus & $\begin{array}{l}\text { level of business farmers' uncertainty about } \\
\text { their price expectation }\end{array}$ & 0.3 \\
\hline simpleCiPlusMinusTrad & $\begin{array}{l}\text { level of traditional farmers' uncertainty about } \\
\text { their price expectation }\end{array}$ & 0.4 \\
\hline simpleCiPlusMinusSupp & $\begin{array}{l}\text { level of supplementary farmers' uncertainty } \\
\text { about their price expectation }\end{array}$ & 0.3 \\
\hline
\end{tabular}

Table 3-1: Initial model parameters

\begin{tabular}{|c|c|c|c|c|}
\hline Farmer type & Name & Parameter description & $\begin{array}{l}\text { Value } \\
\text { (without } \\
\text { crop } \\
\text { revenue } \\
\text { insurance) } \\
\end{array}$ & $\begin{array}{l}\text { Value } \\
\text { (with crop } \\
\text { revenue } \\
\text { insurance) }\end{array}$ \\
\hline \multirow{4}{*}{ Traditional } & $b_{1}$ & $\begin{array}{l}\text { weight of agricultural profit on } \\
\text { decision algorithm }\end{array}$ & 0.34 & 0.30 \\
\hline & $\mathrm{b}_{2}$ & $\begin{array}{l}\text { weight of farmer profile on } \\
\text { decision algorithm }\end{array}$ & 0.40 & 0.52 \\
\hline & $\mathrm{b}_{3}$ & $\begin{array}{l}\text { weight of social network on } \\
\text { decision algorithm }\end{array}$ & 0.09 & 0.05 \\
\hline & $\mathrm{b}_{4}$ & $\begin{array}{l}\text { weight of spatial network on } \\
\text { decision algorithm }\end{array}$ & 0.17 & 0.13 \\
\hline \multirow{4}{*}{ Supplementary } & $b_{1}$ & $\begin{array}{l}\text { weight of agricultural profit on } \\
\text { decision algorithm }\end{array}$ & 0.27 & 0.23 \\
\hline & $\mathrm{b}_{2}$ & $\begin{array}{l}\text { weight of farmer profile on } \\
\text { decision algorithm }\end{array}$ & 0.46 & 0.58 \\
\hline & $\mathrm{b}_{3}$ & $\begin{array}{l}\text { weight of social network on } \\
\text { decision algorithm }\end{array}$ & 0.17 & 0.13 \\
\hline & $\mathrm{b}_{4}$ & $\begin{array}{l}\text { weight of spatial network on } \\
\text { decision algorithm }\end{array}$ & 0.10 & 0.06 \\
\hline \multirow{4}{*}{$\begin{array}{l}\text { Business- } \\
\text { oriented }\end{array}$} & $\mathrm{b}_{1}$ & $\begin{array}{l}\text { weight of agricultural profit on } \\
\text { decision algorithm }\end{array}$ & 0.49 & 0.45 \\
\hline & $\mathrm{b}_{2}$ & $\begin{array}{l}\text { weight of farmer profile on } \\
\text { decision algorithm }\end{array}$ & 0.19 & 0.31 \\
\hline & $\mathrm{b}_{3}$ & $\begin{array}{l}\text { weight of social network on } \\
\text { decision algorithm }\end{array}$ & 0.24 & 0.20 \\
\hline & $\mathrm{b}_{4}$ & $\begin{array}{l}\text { weight of spatial network on } \\
\text { decision algorithm }\end{array}$ & 0.08 & 0.04 \\
\hline \multirow{3}{*}{$\begin{array}{l}\text { Absentee } \\
\text { landowners }\end{array}$} & $b_{1}$ & $\begin{array}{l}\text { weight of agricultural profit on } \\
\text { decision algorithm }\end{array}$ & 0.09 & 0.05 \\
\hline & $\mathrm{b}_{2}$ & $\begin{array}{l}\text { weight of farmer profile on } \\
\text { decision algorithm }\end{array}$ & 0.61 & 0.69 \\
\hline & $\mathrm{b}_{3}$ & $\begin{array}{l}\text { weight of social network on } \\
\text { decision algorithm }\end{array}$ & 0.30 & 0.26 \\
\hline
\end{tabular}




\begin{tabular}{|c|c|c|c|c|}
\hline & $\mathrm{b}_{4}$ & $\begin{array}{l}\text { weight of spatial network on } \\
\text { decision algorithm }\end{array}$ & 0.00 & 0.00 \\
\hline \multirow{4}{*}{ Investor } & $b_{1}$ & $\begin{array}{l}\text { weight of agricultural profit on } \\
\text { decision algorithm }\end{array}$ & 0.08 & 0.04 \\
\hline & $b_{2}$ & $\begin{array}{l}\text { weight of farmer profile on } \\
\text { decision algorithm }\end{array}$ & 0.45 & 0.57 \\
\hline & $b_{3}$ & $\begin{array}{l}\text { weight of social network on } \\
\text { decision algorithm }\end{array}$ & 0.29 & 0.25 \\
\hline & $\mathrm{b}_{4}$ & $\begin{array}{l}\text { weight of spatial network on } \\
\text { decision algorithm }\end{array}$ & 0.18 & 0.14 \\
\hline \multirow{8}{*}{ Traditional } & Fprofile $_{0}$ & $\begin{array}{l}\text { farmer attributes for adopting none } \\
\text { of the practices }\end{array}$ & 0.90 & 1.00 \\
\hline & Fprofile $_{1}$ & $\begin{array}{l}\text { farmer attributes for adopting non- } \\
\text { structural practices }\end{array}$ & 0.68 & 0.96 \\
\hline & Fprofile $_{2}$ & $\begin{array}{l}\text { farmer attributes for adopting } \\
\text { structural practices }\end{array}$ & 0.00 & 0.02 \\
\hline & Fprofile $_{3}$ & $\begin{array}{l}\text { farmer attributes for adopting land } \\
\text { retirement programs }\end{array}$ & 1.00 & 0.00 \\
\hline & Fprofile $_{4}$ & $\begin{array}{l}\text { farmer attributes for adopting } \\
\text { nutrient management plans }\end{array}$ & 0.43 & 0.35 \\
\hline & Fprofile $_{5}$ & $\begin{array}{l}\text { farmer attributes for adopting both } \\
\text { non-structural and structural } \\
\text { practices }\end{array}$ & 0.10 & 0.10 \\
\hline & Fprofile $_{6}$ & $\begin{array}{l}\text { farmer attributes for adopting both } \\
\text { non-structural practices and } \\
\text { nutrient management plans }\end{array}$ & 0.51 & 0.42 \\
\hline & Fprofile $_{7}$ & $\begin{array}{l}\text { farmer attributes for adopting both } \\
\text { structural practices and nutrient } \\
\text { management plans }\end{array}$ & 0.08 & 0.07 \\
\hline \multirow{6}{*}{ Supplementary } & Fprofile $_{0}$ & $\begin{array}{l}\text { farmer attributes for adopting none } \\
\text { of the practices }\end{array}$ & 0.36 & 0.48 \\
\hline & Fprofile $_{1}$ & $\begin{array}{l}\text { farmer attributes for adopting non- } \\
\text { structural practices }\end{array}$ & 0.49 & 1.00 \\
\hline & Fprofile $_{2}$ & $\begin{array}{l}\text { farmer attributes for adopting } \\
\text { structural practices }\end{array}$ & 0.06 & 0.08 \\
\hline & Fprofile $_{3}$ & $\begin{array}{l}\text { farmer attributes for adopting land } \\
\text { retirement programs }\end{array}$ & 1.00 & 0.00 \\
\hline & Fprofile $_{4}$ & $\begin{array}{l}\text { farmer attributes for adopting } \\
\text { nutrient management plans }\end{array}$ & 0.17 & 0.77 \\
\hline & Fprofile $_{5}$ & $\begin{array}{l}\text { farmer attributes for adopting both } \\
\text { non-structural and structural } \\
\text { practices }\end{array}$ & 0.22 & 0.06 \\
\hline
\end{tabular}




\begin{tabular}{|c|c|c|c|c|}
\hline & Fprofile $_{6}$ & $\begin{array}{l}\text { farmer attributes for adopting both } \\
\text { non-structural practices and } \\
\text { nutrient management plans }\end{array}$ & 0.17 & 0.82 \\
\hline & Fprofile $_{7}$ & $\begin{array}{l}\text { farmer attributes for adopting both } \\
\text { structural practices and nutrient } \\
\text { management plans }\end{array}$ & 0.17 & 0.09 \\
\hline \multirow{8}{*}{$\begin{array}{l}\text { Business- } \\
\text { oriented }\end{array}$} & Fprofile $_{0}$ & $\begin{array}{l}\text { farmer attributes for adopting none } \\
\text { of the practices }\end{array}$ & 0.28 & 0.50 \\
\hline & Fprofile $_{1}$ & $\begin{array}{l}\text { farmer attributes for adopting non- } \\
\text { structural practices }\end{array}$ & 0.74 & 0.65 \\
\hline & Fprofile $_{2}$ & $\begin{array}{l}\text { farmer attributes for adopting } \\
\text { structural practices }\end{array}$ & 0.20 & 0.03 \\
\hline & Fprofile $_{3}$ & $\begin{array}{l}\text { farmer attributes for adopting land } \\
\text { retirement programs }\end{array}$ & 0.00 & 0.00 \\
\hline & Fprofile $_{4}$ & $\begin{array}{l}\text { farmer attributes for adopting } \\
\text { nutrient management plans }\end{array}$ & 0.43 & 1.00 \\
\hline & Fprofile $_{5}$ & $\begin{array}{l}\text { farmer attributes for adopting both } \\
\text { non-structural and structural } \\
\text { practices }\end{array}$ & 0.36 & 0.08 \\
\hline & Fprofile $_{6}$ & $\begin{array}{l}\text { farmer attributes for adopting both } \\
\text { non-structural practices and } \\
\text { nutrient management plans }\end{array}$ & 1.00 & 0.66 \\
\hline & Fprofile $_{7}$ & $\begin{array}{l}\text { farmer attributes for adopting both } \\
\text { structural practices and nutrient } \\
\text { management plans }\end{array}$ & 0.28 & 0.08 \\
\hline \multirow{7}{*}{$\begin{array}{l}\text { Absentee } \\
\text { landowner }\end{array}$} & Fprofile $_{0}$ & $\begin{array}{l}\text { farmer attributes for adopting none } \\
\text { of the practices }\end{array}$ & 0.00 & 0.38 \\
\hline & Fprofile $_{1}$ & $\begin{array}{l}\text { farmer attributes for adopting non- } \\
\text { structural practices }\end{array}$ & 1.00 & 0.74 \\
\hline & Fprofile $_{2}$ & $\begin{array}{l}\text { farmer attributes for adopting } \\
\text { structural practices }\end{array}$ & 0.60 & 0.02 \\
\hline & Fprofile $_{3}$ & $\begin{array}{l}\text { farmer attributes for adopting land } \\
\text { retirement programs }\end{array}$ & 0.17 & 0.00 \\
\hline & Fprofile $_{4}$ & $\begin{array}{l}\text { farmer attributes for adopting } \\
\text { nutrient management plans }\end{array}$ & 0.12 & 0.49 \\
\hline & Fprofile $_{5}$ & $\begin{array}{l}\text { farmer attributes for adopting both } \\
\text { non-structural and structural } \\
\text { practices }\end{array}$ & 0.72 & 0.03 \\
\hline & Fprofile $_{6}$ & $\begin{array}{l}\text { farmer attributes for adopting both } \\
\text { non-structural practices and } \\
\text { nutrient management plans }\end{array}$ & 0.31 & 1.00 \\
\hline
\end{tabular}




\begin{tabular}{|c|c|c|c|c|}
\hline & Fprofile $_{7}$ & $\begin{array}{l}\text { farmer attributes for adopting both } \\
\text { structural practices and nutrient } \\
\text { management plans }\end{array}$ & 0.62 & 0.02 \\
\hline \multirow{8}{*}{ Investor } & Fprofile $_{0}$ & $\begin{array}{l}\text { farmer attributes for adopting none } \\
\text { of the practices }\end{array}$ & 0.00 & 0.38 \\
\hline & Fprofile $_{1}$ & $\begin{array}{l}\text { farmer attributes for adopting non- } \\
\text { structural practices }\end{array}$ & 1.00 & 0.74 \\
\hline & Fprofile $_{2}$ & $\begin{array}{l}\text { farmer attributes for adopting } \\
\text { structural practices }\end{array}$ & 0.37 & 0.02 \\
\hline & Fprofile $_{3}$ & $\begin{array}{l}\text { farmer attributes for adopting land } \\
\text { retirement programs }\end{array}$ & 0.48 & 0.00 \\
\hline & Fprofile $_{4}$ & $\begin{array}{l}\text { farmer attributes for adopting } \\
\text { nutrient management plans }\end{array}$ & 0.13 & 0.49 \\
\hline & Fprofile $_{5}$ & $\begin{array}{l}\text { farmer attributes for adopting both } \\
\text { non-structural and structural } \\
\text { practices }\end{array}$ & 0.55 & 0.03 \\
\hline & Fprofile $_{6}$ & $\begin{array}{l}\text { farmer attributes for adopting both } \\
\text { non-structural practices and } \\
\text { nutrient management plans }\end{array}$ & 0.30 & 1.00 \\
\hline & Fprofile $_{7}$ & $\begin{array}{l}\text { farmer attributes for adopting both } \\
\text { structural practices and nutrient } \\
\text { management plans }\end{array}$ & 0.55 & 0.02 \\
\hline
\end{tabular}

Table 3-2: Model parameters comparison for crop revenue insurance scenario. 